\title{
12- Türkçe öğreticileri ve okul yöneticilerinin Suriyeli öğrenciler için açılan uyum sınıfi uygulamasına ilişkin görüşleri
}

Seyfettin KAPAT ${ }^{1}$

Sevilay ŞAHİN²

APA: Kapat, S.; Şahin, S. (2021). Türkçe öğreticileri ve okul yöneticilerinin Suriyeli öğrenciler için açllan uyum sınıfi uygulamasına ilişkin görüşleri. RumeliDE Dil ve Edebiyat Araştırmaları Dergisi, (25), 169-194. DOI: 10.2900o/rumelide.1032424.

$\ddot{O} \mathbf{z}$

Bu çalışmanın amacı, Milli Eğitim Bakanlı̆̆ı'na bağlı olan okullarda Suriyeli öğrenciler için açılan uyum sınıflarına ilişkin Türkçe öğreticileri ve okul yöneticilerinin görüşlerini incelemektir. Araştırma, 2019-2020 eğitim-öğretim yılında Gaziantep’te 10 farklı okulda görev yapan 14 Türkçe öğreticisi ve 13 okul yöneticisi ile gerçekleştirilmiştir. Araştırma, nitel araştırma yöntemlerinden olgubilim deseni ile yürütülmüştür. Verilerin analizinde içerik analizi yöntemi kullanılmıştır. Araştırmadan elde edilen bulgulardan hareketle; uyum sınıflarına devam eden öğrencilerin, uyum sinıflarında daha rahat bir ortam yakaladıkları ancak Türkçeye maruz kalma ve akran öğretimi noktasında sorun yaşadıkları; Türkçe öğreticilerinin uyum sınıfı uygulaması ile kendilerini daha rahat hissettikleri ancak uyum sınıflarının, sınıf mevcutları ve öğrenciler arasındaki seviye farkının Türkçe öğreticilerini olumsuz etkilediği sonucuna ulaşılmıştır. Suriyeli öğrencilere dil eğitiminin okul öncesi dönemde verilmesinin daha verimli olacağı, Türkçe Yeterlik Sınavı'nın yanında mutlaka bir mülakat sisteminin olmasının gerektiği, uyum sınıflarının daha detaylı bir şekilde planlanması gerektiği sonuçlarına ulaşılmıştır. Katılımcıların görüşlerine göre; uyum sınıfların daha etkili ve verimli olabilmesi için; planlamalar gözden geçirilmeli, materyal desteği sağlanmalı, Türkçe öğreticilerinin gelecek belirsizliği giderilmelidir. Araştırma bulgularına dayanarak; yabancı uyruklu öğrencilerin okul öncesi dönemde dil eğitimi almaları, akran öğretimi yönteminin daha sıklıkla uygulanması, uyum sınıflarındaki dil eğitiminin amacının velilere ve öğrencilere daha yoğun anlatılması, uyum sınıflarının planlamasına daha fazla özen gösterilmesi ve Türkçe öğreticilerinin gelecek belirsizliğinin giderilmesi önerilmektedir.

Anahtar kelimeler: Uyum sınıfi, Suriyeli öğrenciler, dil gelişimi, PIKTES

\section{Opinions of Turkish language teachers and school administrators on the application of the integration class for Syrian students}

\begin{abstract}
The aim of this study is to examine the opinions of Turkish language teachers and school administrators regarding the integration classes opened for Syrian students in schools affiliated to the Ministry of National Education. The research was carried out with 14 Turkish language instructors and 13 school administrators working in 10 different schools in Gaziantep in the 20192020 school term. The research was conducted with the phenomenology pattern, one of the
\end{abstract}

Öğretmen, Milli Eğitim Bakanlığı (Gaziantep, Türkiye), seyfettinkapat@gmail.com, ORCID ID: oooo-ooo3-2211-3035 [Araştırma makalesi, Makale kayıt tarihi: 10.11.2021-kabul tarihi: 20.12.2021; DOI: 10.29000/rumelide.1032424] Prof. Dr., Gaziantep Üniversitesi, Eğitim Fakültesi (Gaziantep, Türkiye), ssahin@gantep.edu.tr, ORCID ID: oooo-0002$7140-821 X$

RumeliDE Dil ve Edebiyat Arastrmalar Ddres Osmanağa Mahallesi, Mürver Ciçeği Sokak, No:14/8 Kadıkoy - ISTANBUL T TÜRKIYE 34714 e-posta: editor@rumelide.com tel: +90 $5057958124,+902167730616$
Address

RumeliDE Journal of Language and Literature Studies Osmanağa Mahallesi, Mürver Çiçeği Sokak, No:14/8

Kadıköy - ISTANBUL / TURKEY 34714

e-mail: editor@rumelide.com,

phone: +90 505 7958124, +90 2167730616 
Opinions of Turkish language teachers and school administrators on the application of the integration class for Syrian students / S. Kapat; S. Şahin (pp. 169-194)

qualitative research methods. The data were analysed using the content analysis method. Based on the findings obtained from the research, we determined that student who attend integration classes feel more comfortable in integration classes but have some constrains with exposure to Turkish language and peer learning, Turkish language teachers felt more comfortable in the integration class, but the difference in the level of students and class sizes affected Turkish language instructors negatively. It has been concluded that it would be more efficient to give language education to Syrian students in the pre-school period, that there should be an oral exam besides the Proficiency exam, and that integration classes need more detailed planning. According to the opinions of the participants, for integration classes to be more effective and efficient, plans should be reviewed, material support should be provided and the future uncertainty of Turkish language teachers should be eliminated. According to the opinions of the participants; for integration classes to be more effective and efficient; plans should be reviewed, material support should be provided, the future uncertainty of Turkish teachers should be eliminated. Based on the research findings, It is recommended that foreign students receive language education in the pre-school period, the peer teaching method should be applied more frequently, the purpose of language education in integration classes should be explained more to parents and students, more attention should be paid to the planning of integration classes, and the future uncertainty of Turkish teachers should be eliminated.

Keywords: Integration classes, Syrian students, language development, PIKTES

\section{Giriş}

Suriye'de cereyan eden iç savaş neticesinde, Suriye halkı en yakın sınır komşusu olan Türkiye'ye yönelmiş ve Türkiye, 'açık kapı' politikası ile Suriyelileri kabul etmiştir. Suriyelilerin göç hareketi sonucunda toplumsal alanda bakış açısının değişmesi ve birtakım değişiklikler yapma sonucunu ortaya çıkarmıştır. Bu süreçte Suriyeli öğrencilerin topluma ve Türk eğitim sistemine dâhil edilmesi için çeşitli yasal çalışmalar yürütülmüştür (Yabancılar ve Uluslararası Koruma Kanunu, 2013; Geçici Koruma Yönetmeliği, 2014; Yabancılara Yönelik Eğitim-Öğretim Hizmetleri Genelgesi, 2014).

Suriyeli öğrencilerin eğitim hakkına kavuşması amacıyla eğitim sistemine dâhil edilmesi öğrencilerde uyum problemlerini de beraberinde getirmiştir. Bu kapsamda en ciddi sorun dil sorunu olarak ortaya çıkmaktadır. Nitekim yabancı uyruklu öğrencilerle ilgili araştırmalar incelendiğinde bu konuda benzer sonuçlara ulaşıldı̆̆ı görülmektedir (İstanbul Bilgi Üniversitesi, 2015; Sarıtaş vd., 2016; Mercan Uzun ve Bütün, 2016; Erdem, 2017; Levent ve Çayak, 2017; Tanrıkulu, 2017; Turan ve Polat, 2017; Moralı, 2018; Cırıt-Karaağaç ve Güvenç, 2019; İçöz, 2019; Sarıahmetoğlu, 2019; Takır ve Özerem, 2019; Kandemir ve Aydın, 2020; Özenç ve Kara, 2021). Bunlara ek olarak dil probleminden dolayı akademik başarısızlık yaşadıkları (İmamoğlu ve Çalışkan, 2017; Bulut vd., 2018; Burçak-Kılınç, 2019; Çimşir ve Baysal, 2020), aileden dil eğitimi konusunda yeterli desteği alamayan öğrenciler akranları ve öğretmenleri ile yeterli düzeyde iletişim kuramadıkları için sosyalleşememekte (Mercan Uzun ve Bütün, 2016) ve akranlarıyla iletişim sorunu yaşadıkları (Güngör ve Şenel, 2018; Kuzu Jafari vd., 2018; Uğurlu, 2018; Şimşir ve Dilmaç, 2018) sonuçlarına ulaşılmıştır. Bu sorunun çözümü için gerçekleştirilen uygulamaların en geniş kapsamlı olanı, MEB tarafından yürütülen Suriyeli Çocukların Türk Eğitim Sistemine Entegrasyonunun Desteklenmesi Projesi (PİKTES)'dir. Avrupa Birliği tarafından mali konularda desteklenen PİKTES, geçici koruma altında bulunan çocukların Türk eğitim sistemine erişimlerine katkıda bulunması amacıyla çalışmalar yürütmektedir. 2016 yılında başlayan projenin 2021 yılı Aralık ayına kadar devam etmesi planlanmaktadır (PİKTES, 2020a). Proje kapsamında Türkçe öğreticileri, psikologlar, sosyologlar görevlendirilmesi, öğretmen ve okul yöneticilerine eğitimler verilmesi, dil kursları açılması 
ve okullara materyal ve donatım desteği sağlanması hedeflenmiş (Tüzün, 2017) ve belirlenen tüm hedefler gerçekleştirilmiştir. Bu geniş kapsamlı çalışmalara rağmen Suriyeli öğrencilerin okula uyumları ve akademik gelişimleri istenen düzeye ulaşamamıştır. Sorunun temelinde ise yukarıda verilen ilgili alanyazında belirtildiği gibi dil problemi yatmaktadır. Bu soruna ek bir çözüm olarak Milli Eğitim Bakanlığı yeni bir yöntem olan uyum sınıfı programını başlatmıştır. Uyum sınıfları uygulamasının amacı, Türkçe bilmeyen ya da Türkçe dil beceri düzeylerini geliştirmeye ihtiyacı olan yabancı uyruklu tüm öğrencilere eğitim firsat sunmak, eğitim sonunda bu öğrencileri diğer branş derslerini içeren akademik eğitime hazır hale getirmektir (PİKTES, 2020b). Bu kapsamda MEB (2019), yayımladığı genelge ile uyum sınıfı uygulamasını resmen başlatmıştır. Genelgede dil engeli nedeniyle uyum sorunu yaşayan öğrenciler için uyum sınıfları açılacağı ve ilkokullar için 3 ve 4. sinfflardan öğrenci kabul edileceği, sınıf mevcutları ve ölçme değerlendirme sisteminin nasıl olacağı açıklanmaktadır. Fakat 2020 ylında MEB tarafından yayımlanan 2020/7 sayılı genelge ile 2019/15 sayll genelge yürürlükten kaldırılmış, yeni genelge ile uyum sınıflarının yabancı uyruklu öğrencilerin yoğun olduğu illerde açllacağı, ilkokullarda sadece 3.sınıflardan öğrenci alınacağı ve öğrenci seçiminin Türkçe Yeterlik Sınavı (TYS) yerine okul içerisinde komisyon kararına göre alınacağı belirtilmiştir.

Uygulama başlatılmış fakat süreçte sorunu derinleştiren farklı boyutlar ortaya çıkmıştır. Ara sınıflarda eğitim sistemine dâhil olan yabancı uyruklu öğrenciler için faydalı bir uygulama olarak değerlendirilen uyum sinıfları, okula Türkiye'de başlayıp 1 ve 2 sınıfı Türk eğitim sisteminin içerisinde okuyan öğrenciler açısından dezavantaj olarak ortaya çıtı̆̆ı söylenebilir. Bunun nedeni iki yıl boyunca okula devam eden Suriyeli öğrencilerin okuduklarını anlamlandırmadan okuma yazma öğrenmeleri, ailelerin Türkçe konusunda destek olmamaları/olamamaları, kalabalık sınıflarda Türkçeyi fazla kullanmamaları gibi nedenlerle üçüncü sınıftan başlayan uyum sınffları uygulamasının pek verimli geçmediği söylenebilir.

Bu çerçevede, iki yll boyunca okula devam eden, Türkçe okuyabilen ancak okuduğunu anlamayan ve içerisinde yaşadığı toplumun dili olan Türkçe ile kendini ifade edemeyen öğrenciler ortaya çıkarmıştır. $\mathrm{Bu}$ durum, Suriyeli öğrencilerin ana dilleri ile kendilerini daha rahat ifade ettikleri arkadaşlarıyla iletişime girme zorunluluğu doğurmaktadır. Yabancı uyruklu öğrencilerin yoğun olarak bulunduğu okullarda bazı sınıf mevcutlarının yarısını oluşturan yabancı uyruklu öğrenciler, her geçen sene daha zayıf, hatta çoğu zaman hiç Türkçe bilmeden okula başlamaktadırlar. Bu durum sınıfın okuma yazma gelişimini yavaşlatmakla birlikte sınıf öğretmenlerine de çok ciddi bir iş yükü getirmektedir.

$\mathrm{Bu}$ bağlamda bu araştırma, uyum sınıfı uygulamasının olumlu ve olumsuz yönlerinin farklı bakış açlarıyla incelenerek bu sorunlara çözüm önerileri getirilmesi, açısından önemli görülmektedir. Ayrıca, Türkçe öğreticileri ve okul yöneticilerinin deneyimleri doğrultusunda uyum sinıflarının olumlu ve olumsuz yönlerinin ortaya konulması ve çözüm getirmesi, Suriyeli öğrencilerin dil becerilerinin gelişmesi sonucu okula ve topluma uyumunun hızlanması, sınıf öğretmenlerinin iş yükünü hafifletmesi ve sınıf ortamında daha verimli bir eğitim-öğretim sürecinin yönetilmesi, öğrenciler arasındaki sosyal ilişkileri ve akran öğretiminin gelişmesine katkı sağlayabilmesi açısından önemli görülmektedir.

Bu kapsamda bu araştırmanın temel amacı, Türkçe öğreticileri ve okul yöneticilerinin Suriyeli öğrenciler için açılan uyum sınıfı uygulamasına ilişkin görüşlerini incelemektir.

$\mathrm{Bu}$ amaç çerçevesinde şu sorulara yanıt aranmıştır:

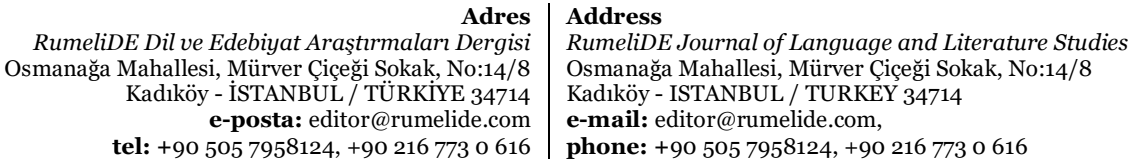

Adres
RumeliDE Dil ve Edebiyat Araşttrmaları Dergisi

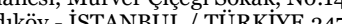
tel: +90 $5057958124,+902167730616$ 
- Türkçe öğreticileri ve okul yöneticilerinin görüşleri doğrultusunda uyum sinıflarının öğrenciler açısından avantajlı ve dezavantajlı yönleri nelerdir?

- Türkçe öğreticileri açısından avantajlı ve dezavantajlı yönleri nelerdir, uyum sınıfların başlama seviyesi hakkındaki görüşleri nelerdir?

- Türkçe Yeterlik Sınavı'nın içerik ve uygulama şekline ilişkin görüşleri nelerdir ve uyum sınıflarının planlamasına (örgütleme, öğretim sürecinin düzenlenmesi, donatım ve materyal desteğinin sağlanması, Türkçe öğreticileriyle ilgili sürecin düzenlenmesi) ilişkin görüşleri nelerdir?

- Uyum sınıflarının daha etkili verimli olabilmesi için tavsiyeler nelerdir?

\section{Yöntem}

\section{Araştırma deseni}

$\mathrm{Bu}$ araştırmada, nitel araştırma desenlerinden fenomenoloji (olgubilim) yöntemi kullanılmıştır. Olgubilim, bireylerin bir olgu veya kavramla ilgili ortak anlamını tanımlar (Creswell, 2013). Olgubilim araştırmalarında, veriler araştırmanın odağını oluşturan olguyu deneyimlemiş ve bu olguyu yansıtabilecek kişilerden toplanır (Yıldırım ve Şimsek, 2018). Bu kapsamda olgubilim çalışması bireylerin yaşadıkları tecrübenin özünü (Creswell, 2013), olguyu nasıl betimlediklerinin (Patton,2014) anlaşılmasını sağlar.

Yorumlayıc fenomenoloji, fenomenle ilgili betimleme yapmanın yanında deneyimlerin anlamının yorumlandığı bir süreçtir (Van Mannen, 1990 akt. Creswell, 2013). Bu çerçevede olgubilim aracılı̆̆ıyla, katılımcıların olguya ilişkin algılarının ve deneyimlerinin ortaya çıarılması amaçlanır (Onat Kocabıyık, 2016). Bu noktadan hareketle; uyum sınıflarının öğrenci ve öğretmen boyutununda avantajlı ve dezavantajlı yönlerinin deneyimlere belirlenmesi ve planlama noktasında farklı bakış açılarının ortaya çıkarılmasına odaklanılmıştır.

\section{Çalışma grubu}

$\mathrm{Bu}$ araştırmada çalışma grubu, amaçlı örnekleme yöntemlerinden ölçüt örnekleme yöntemi tercih edilmiştir. Ölçüt örnekleme yöntemi, belirlenmiş özelliklere sahip bireyler ve olaylardan meydana gelir (Büyüköztürk vd., 2018).

Katılımcıların belirlenmesinde kullanılan ölçüt; öğretmenler için en az 2 yl yabancı uyruklu öğrencilere ders verme, yöneticiler için uyum sınıfı bulunan okullarda görev yapmış olmaktır. Katılımcılarla yapılan görüşmeler gönüllülük esasına göre gerçekleştirilmiştir. Katılımcılara ait demografik bilgiler Tabloı'de verilmiştir.

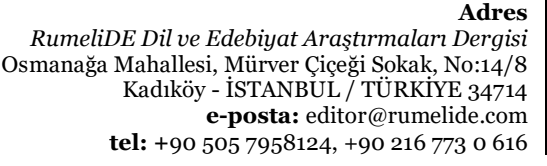

dres

RumeliDE Journal of Language and Literature Studies

Osmanağa Mahallesi, Mürver Çiçeği Sokak, No:14/8

Kadıköy - ISTANBUL / TURKEY 34714

e-mail: editor@rumelide.com,

phone: +90 505 7958124, +90 2167730616 
Tablo 1. Katılımclların demografik bilgileri

\begin{tabular}{|c|c|c|c|c|c|}
\hline Kod & Cinsiyet & Yaş & Öğrenim durumu & Mezuniyet bölümü & $\begin{array}{l}\text { Türkçe öğreticiliği } \\
\text { /yöneticilik yaptığı } \\
\text { zaman (yıl) }\end{array}$ \\
\hline Ö1 & Erkek & 28 & Lisans & Sinıf Öğrt. & 4 \\
\hline Ö2 & Kadın & 27 & Lisans & Sinıf Öğrt. & 3 \\
\hline Ö3 & Kadın & 26 & Lisans & Türkçe Öğrt. & 2 \\
\hline$\ddot{O}_{4}$ & Kadın & 29 & Lisans & Türk Dili ve Edebiyatı & 3 \\
\hline Ö5 & Kadın & 28 & Lisans & Türkçe Öğrt. & 3 \\
\hline Ö6 & Kadın & 25 & Lisans & Sinıf Öğrt. & 3 \\
\hline Ö7 & Kadın & 26 & Lisans & Sinıf Öğrt. & 3 \\
\hline Ö8 & Erkek & 31 & Lisans & Türkçe Öğrt. & 3 \\
\hline Ö9 & Erkek & 28 & Lisans & Sinıf Öğrt. & 3 \\
\hline Ö10 & Kadın & 25 & Lisans & Türkçe Öğrt. & 2 \\
\hline Ö11 & Erkek & 32 & Lisans & Sinıf Öğrt. & 4 \\
\hline Ö12 & Erkek & 27 & Lisans & Türk Dili ve Edebiyatı & 3 \\
\hline Ö13 & Erkek & 28 & Lisans & Rehber Öğrt./Psikolojik Danışman & 3 \\
\hline Ö14 & Kadın & 26 & Lisans & Sinıf Öğrt. & 4 \\
\hline Y1 & Erkek & 41 & Lisans & Sinıf Öğrt. & 12 \\
\hline $\mathrm{Y} 2$ & Erkek & 42 & Lisans & Biyoloji Öğrt. & 14 \\
\hline $\mathrm{Y}_{3}$ & Erkek & 28 & Lisans & Sinıf Öğrt. & 1 \\
\hline $\mathrm{Y}_{4}$ & Erkek & 45 & Lisans & Sınıf Öğrt. & 4 \\
\hline $\mathrm{Y}_{5}$ & Erkek & 62 & Ön Lisans & Sinıf Öğrt. & 30 \\
\hline Y6 & Erkek & 38 & Lisans & Sinıf Öğrt. & 1 \\
\hline $\mathrm{Y}_{7}$ & Erkek & 51 & Lisans & İşletme & 12 \\
\hline Y8 & Kadın & 26 & Lisans & Rehber Öğrt./Psikolojik Danışman & 1 \\
\hline Y9 & Erkek & 33 & Lisans & Rehber Öğrt./Psikolojik Danışman & 3 \\
\hline Y10 & Erkek & 35 & Lisans & Sinıf Öğrt. & 4 \\
\hline Y11 & Erkek & 42 & Yüksek lisans & Sinıf Öğrt. & 12 \\
\hline Y12 & Kadın & 49 & Lisans & Sinıf Öğrt. & 8 \\
\hline Y13 & Erkek & 40 & Lisans & Sinif Öğrt. & 10 \\
\hline
\end{tabular}

Araştırma kapsamında görüşülen katılımcılara ait demografik bilgiler Tablo 1'de verilmiştir. Tablo 1 incelendiğinde; katılımcıların cinsiyete göre dağılımları, \%63’e, \%37 şeklinde erkekler lehine ağırlık olduğu; katılımcıların öğrenim durumları incelendiğinde, \%96'sının lisans mezunu olduğu; katılımcıların mezuniyet bölümleri incelendiğinde sınıf öğretmenliği mezunu olanlar \%59 iken \%41'inin branş öğretmeni olduğu; Türkçe öğreticilerinin mesleki kıdemleri incelendiğinde, 2-4 yll tecrübeye sahip olduğu; okul yöneticilerinin mesleki kıdemleri incelendiğinde ise katılımcıların 1-30 yl arası okul idareciliği tecrübesi olduğu görülmektedir. Kişisel bilgilerin gizliliğini sağlamak amacıyla katılımcı öğretmenler Ö1, Ö2... şeklinde, okul yöneticileri Y1, Y2... şeklinde kodlanmıştır.

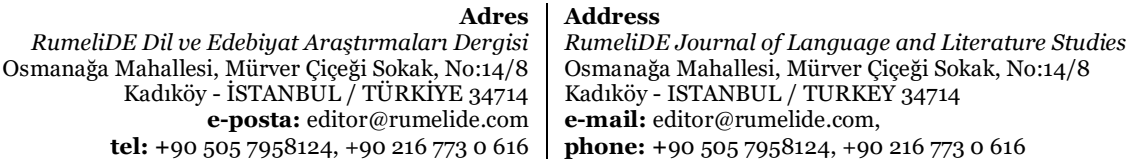




\section{Veri toplama aracı}

Araştırmada, uyum sınıfı öğretmenlerinin ve okulunda uyum sınıfı bulunan okul yöneticilerinin görüşlerini belirleyebilmek amacıyla görüşme tekniği kullanılmıştır. Nitel araştırmalarda sıklıkla kullanılan bir yöntem olan görüşme (Creswell, 2019); katılımcıların bakış açılarını, deneyimlerini (Karataş, 2015), daha rahat bir ortamda aktarmasına olanak sağlaması (Yüksel ve Yüksel, 2004 akt. Tanrısevdi vd.,2019) avantajından dolayı tercih edilmiştir. Bu çerçevede verilerin toplanması amacıyla yarı yapılandırılmış görüşme formu kullanılmıştır. Yarı yapılandırılmış görüşme, farklı sorularla görüşme konusunun detaylandırılması ve konu hakkında yeni bilgilere ulaşılması açısından önemlidir (Merriam, 2018).

Yarı yapılandırılmış görüşme formu, alanyazından elde edilen veriler ve uygulamada karşılaşılan durumlar temel alınarak hazırlanmıştır. Görüşme soruları, okullarda doğrudan görülebilen ve süreci doğrudan etkileyen durumlar olmasından dolayı uyum sınıflarının uygulanması sürecinde yaşanan deneyimler, planlama, TYS ve uyum sınıflarının başlama düzeyi kapsamında ele alınmış ve bu çerçevede incelenmiştir. Görüşme formunun birinci bölümünde katılımcılara ilişkin demografik bilgilere yer verilmiştir. İkinci bölümde ise, uzman görüşleri alınan ve pilot uygulaması yapılan aşağıda maddeler halinde siralanan sorular sorulmuştur.

1. Uyum sınıflarının Suriyeli öğrenciler açısından avantajlı yönleri nelerdir? Neden?

2. Uyum sınıflarının Suriyeli öğrenciler açısından dezavantajlı yönleri nelerdir? Neden?

3. Uyum sınıflarının Türkçe öğreticileri açısından avantajlı yönleri nelerdir? Neden?

4. Uyum sınıflarının Türkçe öğreticileri açısından dezavantajlı yönleri nelerdir? Neden?

5. Uyum sınıflarının 3.sınıfta başlamasını nasıl değerlendirirsiniz? Size göre nasıl olmalıdır? Neden?

6. Türkçe Yeterlik Sınavı (TYS) (uygulanma zamanı, şekli, sınav içeriği vs. ) hakkındaki görüşleriniz nelerdir? Neden?

7. Uyum sınıflarının planlamasında olumlu ve olumsuz gördüğünüz uygulamalar nelerdir? Neden?

8. Uyum sınıfların daha etkili ve verimli olabilmesi için tavsiyeleriniz nelerdir?

Görüşmeler yapılmadan önce katılımcılar görüşme hakkında bilgilendirilmiştir. Görüşmeyi kabul eden katılımcılarla görüşmeler gerçekleştirilmiştir. Görüşme esnasında katılımcıların söylemlerini kaçırmamak amacıyla katılımcılardan izin alınarak görüşmeler ses kaydıyla toplanmıştır. İki katılımcı ses kaydı alınmasını kabul etmemiştir. Söz konusu katılımcıların görüşleri not alınmıştır. Görüşmeler 04.02.2020 - 04.03.2020 tarihleri arasında gerçekleştirilmiştir. Türkçe öğreticileriyle yapılan görüşmeler ortalama 41 dakika, okul yöneticileriyle yapılan görüşmeler ortalama 36 dakika sürmüştür. Görüşmeler esnasında muğlak kelimelerin ve cümlelerin net anlaşılması amacıyla katılımcılardan görüşlerini detaylandırması istenmiş, görüşlerin doğru anlaşılıp anlaşılmadığını teyit etmek amacıyla dönütler verilmiştir.

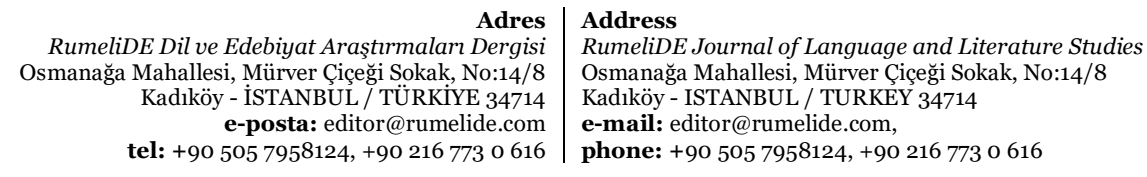




\section{Verilerin analizi}

Araştırma verileri, tümevarımsal içerik analizi yöntemi ile analiz edilmiştir. İçerik analizinde amaç, elde edilen verileri açıklamaya yarayacak kavram ve temalara ulaşmaktır (Yıldırım ve Şimşek, 2016). Bu amaç doğrultusunda, katılımcılardan ses kayıt yolu ile elde edilen veriler öncelikle bilgisayar ortamında yazılı hale getirilmiştir. Daha sonra katılımcıların yanıtları detaylı bir şekilde incelenerek kodlar oluşturulmuştur. Kodların çatısını oluşturması amacıyla kategoriler, kategorilerin çatısını oluşturması amaciyla temalar oluşturulmuştur.

\section{Geçerlik ve güvenirlik çalışmaları}

Paker (2015), nitel araştırmalarda güvenirliğin sağlanması amacıyla araştırma sürecinin açıkça tanımlanması ve verilerle kanıt sağlanması gerektiğini belirtmektedir. Bu çerçevede araştırmanın iç geçerliğini (inandırıcılık) sağlamak amacıyla, görüşmeler esnasında katılımcılara sürekli dönüt verilerek doğru anlaşılıp anlaşılmadığı ölçülmüş ve katılımcıların teyit etmesi sağlanmıştır. Elde edilen veriler, bulgular bölümünde doğrudan alıntı yoluyla raporlaştırılmıştır. Aynı zamanda görüşme formu için hazırlanan sorular eğitim yönetimi alanında 2 akademisyenin görüşüne sunulmuştur.

Dış geçerlik (aktarılabilirlik) kapsamında, katılımcılar ile ilgili bilgiler detaylı bir şekilde raporlaştırılmış ve katılımcılardan elde edilen veriler ayrıntılı bir şekilde kod, kategori ve temalar şeklinde betimlenmiştir.

İç güvenirlik (tutarlıık) çalışması kapsamında, katılımcılardan elde edilen veriler 30 gün arayla iki defa çözümlenmiştir.

Dış güvenirlik (teyit edilebilirlik) noktasında, katılımcılardan elde veriler muhafaza edilmekte ve ihtiyaç duyulduğunda teyit edilmeye hazır tutulmaktadır.

\section{Bulgular}

Araştırmanın bu bölümünde, ilkokullarda görev yapan Türkçe öğreticileri ve okul yöneticilerinin 3.sınıftan itibaren uygulanan uyum sınıfı uygulamasına ilişkin görüşleri doğrultusunda elde edilen verilerin analizi sonucunda oluşturulan tema, kategori ve kodlar sunulmuştur. Elde edilen bulgular temalar şeklinde ele alınmış ve doğrudan alıntı yöntemiyle desteklenmiştir.

\section{Türkçe öğreticileri ve okul yöneticilerinin uyum sınıfı uygulamasının Suriyeli öğrenciler açısından avantaj ve dezavantajlarına ilişkin görüşleri}

Tablo 2. Türkçe öğreticileri ve okul yöneticilerinin uyum sınıfı uygulamasının Suriyeli öğrenciler açısından avantajlarına ilişkin görüşleri

\begin{tabular}{|c|c|c|c|}
\hline Tema & Kategori & \multicolumn{2}{|l|}{ Kod } \\
\hline \multirow{6}{*}{ Avantajları } & \multirow{6}{*}{ Akademik Gelişim } & \multicolumn{2}{|c|}{ Okuma yazma becerilerinde artışın olması } \\
\hline & & \multicolumn{2}{|c|}{ Türkçeye daha fazla zaman ayrılması } \\
\hline & & \multicolumn{2}{|c|}{ Öğrencilerin seviyelerine göre ders verilmesi } \\
\hline & & \multicolumn{2}{|c|}{ Türkçeyi kullanmada artışın olması } \\
\hline & & \multicolumn{2}{|c|}{ İlerlemenin daha kolay olması } \\
\hline & & \multicolumn{2}{|c|}{ Okuma yazmaya daha fazla zaman ayrılması } \\
\hline & $\begin{array}{r}\text { RumeliDE Dil ve Ed } \\
\text { Osmanağa Mahallesi, } \\
\text { Kadıköy }-\dot{\mathrm{I}} \\
\text { e- } \\
\text { tel: }+90505\end{array}$ & $\begin{array}{r}\text { Adres } \\
\text { armaları Dergisi } \\
\text { i Sokak, No:14/8 } \\
\text { TÜRKIYE } 34714 \\
\text { r@rumelide.com } \\
90216773 \text { o } 616\end{array}$ & $\begin{array}{l}\text { Address } \\
\text { RumeliDE Journal of Language and Literature Studies } \\
\text { Osmanağa Mahallesi, Mürver Çiceği Sokak, No:14/8 } \\
\text { Kadıköy - ISTANBUL / TURKEY } 34714 \\
\text { e-mail: editor@rumelide.com, } \\
\text { phone: +90 505 7958124, +90 } 216773 \text { o } 616\end{array}$ \\
\hline
\end{tabular}


Öncelikli konulara eğildiğimiz için daha kolay öğrenmelerin olması

Türkçeye odaklanılması

Anlama becerilerinde artışın olması

\begin{tabular}{ll}
\hline Fiziksel Durum & Sınıf mevcutlarının daha az olması \\
& Arkadaş çevresi ile birlikte olunmasının sağlanması \\
& Müstakil sınıfların olması \\
\hline Öğrencilerin kendilerini daha rahat hissetmesi & Birebir ilgilenme olanağının olması \\
& Öğrencinin öğretmeni benimsemesi \\
Duygusal Gelişim & Başarısızlık duygusunun önüne geçilmesi \\
& Öğrencilerin sınıfı sahiplenmesi \\
\hline & Aynı seviyedeki öğrencilerin bir arada olması \\
& Öğrencilerin sosyalleşmesinin artması \\
& Kendilerini ifade etme olanağının sunulması \\
& Aynı kültürden geldikleri için daha iyi anlaşmaların olması \\
& Öğrencinin özgüveninde artışın olması \\
& Kendisini daha rahat ifade etme imkânı bulması
\end{tabular}

Uyum sınıfı uygulamasının uyum sınıfı öğrencileri açısından kazanımlarının yer aldığı Tablo 2 incelendiğinde; akademik gelişim, fiziksel durum, duygusal gelişim ve sosyal gelişim olmak üzere 4 kategoriden oluştuğu görülmektedir. Uyum sınıflarının öğrenciler açısından değerlendiren okul yöneticileri ve Türkçe öğreticilerinin görüşleri genel olarak paralellik gösterirken, Türkçe öğreticileri akademik gelişimin üzerinde daha fazla durdukları gözlemlenmiştir.

Uyum sınıfı uygulamasının öğrencilerin akademik gelişim ile ilgili olarak katılımcı Ö12; "bu onlar açısından belki süre yetersiz olabilir. Ne kadar öğretileceği tartışlabilir ama bazı eksiklikleri (bulunmaktadır). En azından A1,A2 seviyesinde kendini ifade etme, arkadaşlarılyla muhabbet edebilme, konuşabilme açısından bunları rahatlkkla öğrenebiliyorlar. Tabi bunu yazmaya okumaya da indirgeyebiliriz. Akademik anlamda çocuklarm kesinlikle geliştiğini düşünüyorum”; katılımcı Ö13, "eski sımflarında iyi olan çocuklar var. Eski sinıflarmda sönük öğrenciler olabiliyorlardı. Ama şimdi yeni sınıflarında öğretmenleri onlarm seviyesinde üç aşağı beş yukarı zaten hepsi aynı hepsine yönelik ayn eğitimi verebildi yani eğitimsel açıdan öğrenciler daha çok gelişti”; Ö14 ise, “...okuma yazma bilmeyen öğrencilerin okuma yazmaların biraz geliştirmelerine yardımcı oldu.” şeklinde görüş belirtmiştir.

Fiziksel durum ile ilgili olarak katılımcı Ö3; "öğrenciler kendi arkadaş çevreleri ile birlikte oldukları için çok rahatlar, (onlar için) daha rahat bir ortak oluyor.”; katılımcı Y5 ise, "öğrenciler bir arada olduğu için yalnızhk hissi yaşamadılar." şeklinde ifade etmiştir.

Duygusal gelişim noktasında ise katılımcı $\mathrm{Y}_{7}$; “çocuklar normal kendi sınıflarında bulunurken bazı çocuklar bunları (Suriyeli öğrencileri) dişlıyor ama uyum sınıflarmda çocuklar kendilerini daha rahat hissediyor."; katılımcı Y8, "kendini ifade etme açısından bence daha iyi oldu. Çünkü kendileri gibi olan öğrencileri gördüler. Diğer sinıflarda biraz daha belki azınlı durumundaydılar.”; katılımcı Y7,

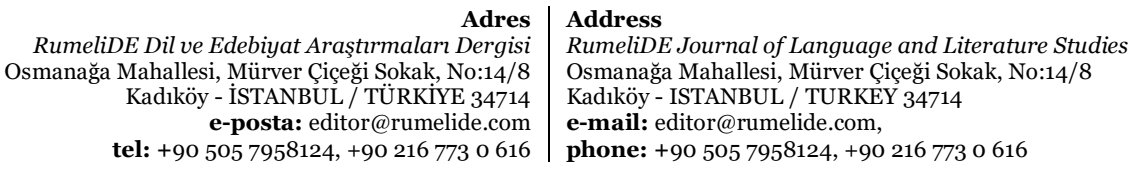


“...öğretmenlerin öğrenciyle birebir ilgilenmesi öğrenci başarısını da arttırıyor.”; katılımcı Ö13; "çünkü daha çocuklar bütün olarak aynı simıfta. Farkh etnik kökenden olmadıkları için, aym toplumdan oldukları için kendilerini daha olumlu anlamda gösterdiler.” şeklinde ifadeler kullanmışlardır.

Sosyal gelişim katılımcı Y8; “(uyum sinıfları) öncelikle öğrencilerin sosyalleşmesi açısından önemliydi. Çünkü Çocuklar kendi sımıflarında kendilerini çok fazla ifade edemedikleri için... Açıkçası hem biraz böyle kendi aralarında gruplaşmalar oluyordu (Eski sinıflardaki durumdan bahsediyor).”; katılımcı Ö11; “(öğrencilerin) okuma yazmasını destekliyoruz. (Uyum) sinıflarında çocukların özgüveni daha yüksek oluyor Benim sinıfimda özgüveni yüksek olan çocuk kendi sınıfina gidince içine kapanmaya başladı.” sözleriyle ifade etmiştir.

Tablo 3. Türkçe öğreticileri ve okul yöneticilerinin uyum sınıfı uygulamasının Suriyeli öğrenciler açısından dezavantajlarına ilişkin görüşleri

\begin{tabular}{|c|c|c|}
\hline Tema & Kategori & Kod \\
\hline \multirow{26}{*}{ Dezavantajları } & \multirow{11}{*}{ Duygusal Gelişim } & Okula entegrasyonun gecikmesi \\
\hline & & İzole sınıf hissiyatının doğması \\
\hline & & Ö̈̆grencilerdeki ayrışmışlık duygusunun oluşması \\
\hline & & Türk öğrencilerden ayrılmaları \\
\hline & & Dışlanmışlık hissi \\
\hline & & Kültür kaynaşmasının olmaması \\
\hline & & Kapalı kültür haline dönüşme \\
\hline & & Suriyeli sınıfı algısının oluşması \\
\hline & & Uyum sınıflarının ayrı tutulması \\
\hline & & Türk öğrencilerle kaynaşmanın engellenmesi \\
\hline & & Uyum sınıflarına alışmanın olması \\
\hline & \multirow{5}{*}{ Dil Gelişimi } & Arapça konuşmanın yaygınlaşması \\
\hline & & Türkçe öğrenme zorunluluğu hissetmemeleri \\
\hline & & Akran öğrenmesinin olmaması \\
\hline & & Bazı dersleri Türk öğrencilerle almamaları \\
\hline & & Türkçeye maruz kalmamaları \\
\hline & \multirow{10}{*}{ Ĕ̆itim-Ö $\breve{g r e t i m}$} & Devamsızlığın artması \\
\hline & & Öğrenciler arasında seviye farkının olması \\
\hline & & Kitapların öğrenciler için yetersiz olması \\
\hline & & Okuma yazma bilmeyenlerin varlığı \\
\hline & & Türkçe dil ediniminin olumsuz etkilenmesi \\
\hline & & Kendi sınıflarından ayrılmaları \\
\hline & & Akran öğrenmesinin olmaması \\
\hline & & Türkçeyi sadece öğretmenden duymaları \\
\hline & & Dil öğreniminin yavaş olması \\
\hline & & Türkçe bilenlerle etkileşimin azlığı \\
\hline & $\begin{array}{r}\text { Adres } \\
\text { RumeliDE Dil ve Edebiyat Arassturmaları Dergisi } \\
\text { Osmanağa Mahallesi, Mürver Ciçeği Sokak, No:14/8 } \\
\text { Kadıköy - İSTANBUL / TÜRKIYE } 34714 \\
\text { e-posta: editor@rumelide.com } \\
\text { tel: +90 505 7958124, +90 } 2167730616\end{array}$ & $\begin{array}{l}\text { Address } \\
\text { RumeliDE Journal of Language and Literature Studies } \\
\text { Osmanağa Mahallesi, Mürver Ciceği Sokak, No:14/8 } \\
\text { Kadıöy - ISTANBUL / TURKEY } 34714 \\
\text { e-mail: editor@rumelide.com, } \\
\text { phone: +90 505 7958124, +90 } 216773 \text { o } 616\end{array}$ \\
\hline
\end{tabular}


Uyum sınıfı uygulamasının uyum sınıfına devam eden öğrenciler açısından dezavantajlarının yer aldığı Tablo 3 incelendiğinde; duygusal gelişim, dil gelişimi ve eğitim-öğretim olmak üzere 3 kategorinin oluştuğu görülmektedir. Uyum sınıflarını öğrenciler için dezavantajlı yönlerini değerlendiren katılımcıların büyük çoğunluğu, öğrencilerin izole sınıf algılarının varlığından, dışlanmışlık hissi yaşadıklarından söz etmişlerdir.

Duygusal gelişim ile ilgili olarak katılımcı Ö1; "diğer öğrencilerin Suriyeli sımıfı gibi algıları olmasından dolayı uyum sınıfindaki öğrenciler ister istemez olumsuz etkilenebiliyor, biraz dışlanmış hissedebiliyorlar. Okul içerisinde yapılan uygulamalarda uyum sinıfinın ve öğrencilerinin ayrı tutulması öğrencileri olumsuz etkileyebiliyor"; katılımcı $Y_{5}$, "çocuklar ayrlmış, sınırı ötesine atılmış bir grup gibi olduğu için fayda alınamıyor." ; katılımcı Y4, "yani bence en büyük sorun o kendi sinıfindan alını başka bir sımıfta toplanması... Bir de hep aynı mülteci çocukların bir arada olması sanki izole edilmiş gibi olumsuz görünen”; katılımcı Y1, “öğrencilerin izole olmaları, öğrencilerin okula uyumunu zorlaşttrdığı için davranış ve disiplin problemleri meydana gelmektedir.” görüşünü savunmaktadır. şeklinde görüş belirtmiştir.

Öğrencilerin dil gelişimleri ile ilgili olarak katılımcı Y9; “geçen seneki uygulamada Suriyeli öğrenciler Türkçeye daha fazla maruz kahyorlardı. Çünkü sınıfinda hem Türk öğrenciler hem öğretmen Türkçe konuşuyordu. Şimdiki uygulamada sadece öğretmen Türkçe konuşuyor, akranları (ile) Türkçe konuşamıyorlar ya da çok az konuşuyorlar"; katılımcı Y10, "akran eğitimi olmadiğı için en önemli şey kendi aralarında da ayn dili konuşacakları için faydah olacağın düşünmüyorum. Olmadı yani...”; katılımcı Ö10, "kendi aralarında az önce de söylemiştim teneffüste işte derste silgi aldım, ona verdim gibi bir şeyler konuşurken bile şey Arapça konuşuyorlar"; katılımcı Y13, "Türkçe öğrenmeyi kendilerine mecbur görmüyorlar. Sanıyorum teneffüslerde, derslerde, kendi aralarnda sürekli Arapça konuştukları için... Bundan dolayı Türkçeleri fazla gelişmedi. Yani pratikte geliştiremediler.”; katılımcı Ö7, "Türkçe öğretimini olumsuz etkiledi. Çocuk benim dışımda (Türkçeyi) pekiştiremiyorlar. O açıdan sıkıntı. Şimdi nasıl desem, sınıfta evet sadece ben Türkçe biliyorum. Arkadaşları Arapça biliyor. Benim tekrarlarm dışında pekiştiremiyorlar"; katılımcı Ö3, "Türk sınıflarında olsa biraz da Türkçeye maruz kalır örnek vereyim mesela çocuklar Türkçe renklerin hepsini biliyorlar. Çok güzel. Ama birbirlerinden mesela boya kalemi istediklerinde yine Arapça istiyorlar ama Türk sinıfinda olsa mecburen Türkçe isteyecek. Zorunda kalacak...” görüşünü savunmaktadır.

\section{Türkçe öğreticileri ve okul yöneticilerinin uyum sınıfı uygulamasının Türkçe öğreticileri açısından avantaj ve dezavantajlarına ilişkin görüşleri}

Tablo 4. Türkçe öğreticileri ve okul yöneticilerinin uyum sınıfı uygulamasının Türkçe öğreticileri açısından avantajlı yönlerine ilişkin görüşleri

\begin{tabular}{|c|c|c|}
\hline Tema & Kategori & Kod \\
\hline \multirow{7}{*}{ Avantajlar } & \multirow{6}{*}{ Fiziksel Durum } & Müstakil sınıfın olması \\
\hline & & Belirli öğrencilerin olması \\
\hline & & Belirli bir düzenin olması \\
\hline & & Nispeten daha az öğrencinin olması \\
\hline & & Sınıfin bize ait olması \\
\hline & & Daha rahat hareket imkânı sağlaması \\
\hline & Duygusal Durum & Öğretmen gibi hissetme \\
\hline & $\begin{array}{r}\text { Adres } \\
\text { RumeliDE Dil ve Edebiyat Arassturmaları Dergisi } \\
\text { Osmanağa Mahallesi, Mürver Ciçeği Sokak, No:14/8 } \\
\text { Kadıköy - İSTANBUL / TÜRKIYY } 34714 \\
\text { e-posta: editor@rumelide.com } \\
\text { tel: + }+90 \text { 505 7958124, +90 } 2167730616\end{array}$ & $\begin{array}{l}\text { Address } \\
\text { RumeliDE Journal of Language and Literature Studies } \\
\text { Osmanağa Mahallesi, Mürver Cicceği Sokak, No:14/8 } \\
\text { Kadıköy - ISTANBUL / TURKEY } 34714 \\
\text { e-mail: editor@rumelide.com, } \\
\text { phone: +90 505 7958124, +90 } 216773 \text { o } 616\end{array}$ \\
\hline
\end{tabular}


Okula bağlılı̆̆ arttırması

Sahiplenme duygusunun oluşması

Belirli seviye grubuna ders verilmesi

Öğrenciler hakkında detaylı bilgi sahibi olunması

Ĕ̆itim-öğretim

Öğrencilerin devamsızlık takibinin kolaylaşması

Öğrencilerin akademik takibini kolaylaştırması

Öğrencilerle yakın ilişki kurmaya imkan sağlaması

Uyum sınıfı uygulamasının Türkçe öğreticileri açısından avantajlarının yer aldığı Tablo 4 incelendiğinde; fiziki durum, duygusal gelişim ve eğitim-öğretim olmak üzere 3 kategoriden oluştuğu görülmektedir. Türkçe öğreticilerinin fiziksel duruma çok vurgu yaptı̆̆ı görülürken okul yöneticilerinin ise eğitim-öğretime daha çok vurgu yaptıkları görülmüştür.

Fiziki durum kategorisinde müstakil sınıfın olması noktasında katılımcı Ö7; "sınıf açısından çok büyük avantajımız oldu. Diğer türlü sınıfimız belli değildi, nereden nereye girdiğimiz belli bir düzen yoktu. Öğrenci(-leri sinfflarmdan) topluyorduk ama bu şekilde öğrencilerin bizim sinıfta olduğu belli oldu. En azından ben kendi takibimi sağliyorum”; katılımcı Ö12; "o sımıfın bize ait olduğunu bilmek çok güzel. Yani bütün Türkçe öğreticilerinin hemfikir oldukları nokta belli bir düzenimizin olmasl, sınıfimızın olması"; katılımcı Ö11; "öğrencilerimiz belli, bir sistem olunca (daha etkili sonuç alıyoruz)... Mesela bir hafta sonra bu çocuklarn gelecek (mi) gelmeyecek mi kaygısı yok. Sonuna kadar yapacağım planlamalar (-ı yapabiliyorum)... Çocuk ne öğrenecek o belli. Öğrenciler için faydası var. Bizim için de var.” şeklinde görüş beyan etmiştir.

Duygusal durum kategorisinde katılımcı Y12; "tüm öğretmenlerin bizim öğretmenimiz olduğunu özellikle belirttik. Bu Türkçe öğreticilerinin hoşuna gidiyor ve okula bağhllkların arttırıyor. Türkçe öğreticilerimiz çok mutlu. Çeşitli etkinlikler yapıyorlar, okul geneli programlar düzenliyorlar”; katılımcı Ö1, "resmi olarak kendi öğrencilerimin ve sınıfımın olması daha rahat hissetmemi sağluyor. Bu durum okula bağhlhğımızı arttırdı."; katılımcı Ö6; "diğer öğretmenler tarafindan bir öğretmen olarak kabul ediliyoruz artık. Bu da bizi motive etti”; katılımcı Ö4 ise, "(uyum sinıflarindan önce) 'ne zaman derse gireceğim, öğrencilerim kim?’ gibi bir karmaşa vardı. Ama şu anda belli sinıfimız ve öğrencilerimizin olması biraz daha öğretmen gibi hissetmemizi sağladı.” şeklinde belirtmiştir.

Eğitim-öğretim kategorisinde katılımcı Y6, "bence belirli seviye grubuna ders verildiği için (Türkçe öğreticilerinin) işleri daha kolay oldu”; katılımcı Y8, "önceki yıllarda öğrencilerle ilgili soru sorduğumuzda pek hakim değillerdi (Türkçe öğreticileri). Ama şimdi ailesinden tutun da biraz daha tanıma amaçh daha iyi olduğunu düşünüyorum"; katılımeı Ö7 ise, "en azından ben kendi takibimi sağ liyorum. Onlarla daha yakından ilişki kurabiliyorum.” şeklinde görüş belirtmiştir.

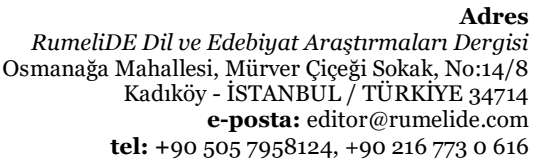

Adres

RumeliDE Journal of Language and Literature Studies

Osmanağa Mahallesi, Mürver Çiçeği Sokak, No:14/8

Kadıköy - ISTANBUL / TURKEY 34714

e-mail: editor@rumelide.com,

phone: +90 5057958124 , +90 2167730616 
Tablo 5. Türkçe öğreticileri ve okul yöneticilerinin uyum sınıfı uygulamasının Türkçe öğreticileri açısından dezavantajlı yönlerine ilişkin görüşleri

\begin{tabular}{lll}
\hline Tema & Kategori & Kod \\
\hline & & Öğrenciler arasındaki seviye farkının çok olması \\
& Öğrencilerin seviyesinin düşük olması \\
\cline { 2 - 3 } Dezavantajları Ö̆̆grenmesi & Sınıf mevcutlarının fazla olması \\
\cline { 2 - 3 } & Akademik ilerlemenin yavaş olması \\
& Öğrenme güçlüğü yaşayan öğrencilerin olması \\
\cline { 2 - 3 } & Çalışma Koşulları & Birleştirilmiş sınıf öğretmeni gibi çalışılması \\
& Sinıf mevcutlarının fazla olması \\
& Sürekli nakil öğrenci gelmesi \\
& İş yükünün artması \\
\hline
\end{tabular}

Uyum sınıfı uygulamasının Türkçe öğreticileri açısından dezavantajlarının yer aldığı Tablo 5 incelendiğinde; öğrenci öğrenmesi ve çalışma koşulları olmak üzere 2 kategoriden oluştuğu görülmektedir. Bu başlık altında okul yöneticileri, ciddi bir dezavantaj görmediklerinden dolayı pek görüş belirtmemişlerdir.

Öğrenci öğrenmesi kategorisinde öğrenciler arasındaki seviye farkı ile ilgili olarak katılımcı Ö14, "sınıf üç kısımda şu an; iyi, çok iyi ve sıfır olanlar hatta orta diye bir seviye bile var"; katılımcı Ö6 ise, "şimdi sadece Türkçeye odaklandık. Sadece Türkçe öğretiyoruz. Şimdi bilen de var, bilmeyen de var. Okuma yazma bilen de var bilmeyip Türkçeyi çok güzel konuşan da var. Şimdi seviye farkı çok çok fazla.”; iş yükünün artması noktasında katılımcı Y11, "seviyesi çok düşük olan öğrenciler öğretmenlerin üzerindeki iş yükünü arttırd»”; katılımcı Ö1 ise, “okuma yazması zayıf veya hiç olmayan öğrencilerin okuma yazmalarmı ve Türkçelerini geliştirmeye çalışıyoruz. Bir nevi birleştirilmişs sinıf öğretmeni gibi çalışıyoruz."; sınıf mevcutları ile ilgili olarak katılımcı Ö4; "en önemli olumsuz yanı mevcut 3o. Sayı çok çok fazla. Dil öğretiminde en fazla 15, yani 10 ile 15 arasında olması gerekiyor. Tüm simıflarn sayısı 30 olması çok sıkıntı"; katılımcı Ö12 ise, "sınıf mevcudu ayrı bir eleştiri konusu. Dil öğretiminde en fazla 15 kişi ya da 20 kişi olması lazım. Çünkü dil öğretimi o kadar hassas ki öğrencilerle bire bir ilgilenmek, bire bir diyalog kurmak gerek. (Sinf mevcudunu)en az 10, en fazla 3o(olması gerekir). 30 kişiden sonra bir sinıf daha açllyor. Benim sınıfim 30 kişiydi, 15 kişi olmasını çok isterdim. Hepsine yetişmek zor oluyor.” şeklinde görüş belirtmiştir.

Çalışma koşulları kategorisinde katılımcı Ö5, "çok fazla nakil öğrenci geliyor. Normalde seviyeyi ayarlamak zaten zor oluyordu. Sürekli nakil gelince daha da zorlanıyoruz"; katılımcı Ö13 ise, "uyum sinıfları kalabalık olduğu için öğrenme açısından güçlük yaşayan öğrencilerde çok zorlanıyoruz.” şeklinde görüş belirtmiştir.

\section{Uyum sınıflarının uyum sınıflarının başladığı sınıf seviyesine yönelik görüşler}

Uyum sınıfı uygulaması hâlihazırda 3.sınıf seviyesinde başlamaktadır. Bu başlık altında uyum sınıfı uygulamasının Türkçe öğreticileri ve okul yöneticilerinin görüşlerine göre başlama yaşına ilişkin tema, kategori ve kodlara yer verilmiştir.

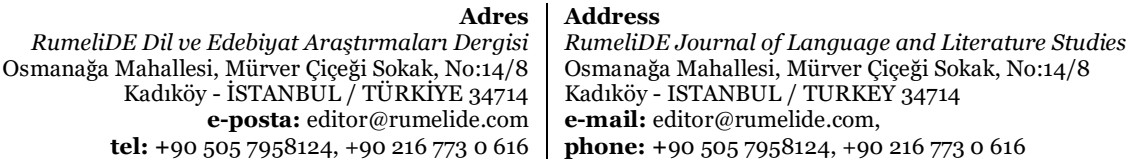

Adres
RumeliDE Dil ve Edebiyat Araşttrmaları Dergisi adköy - İTẢ el: +90 $5057958124,+902167730616$

phone: +90 505 7958124, +90 2167730616 
Tablo 6. Türkçe öğreticileri ve okul yöneticilerinin uyum sınıfı uygulamasının Türkçe öğreticilerinin uyum sınıflarının başlama zamanına ilişkin görüşleri

\begin{tabular}{lll}
\hline Tema & Kategori & Kod \\
\hline \multirow{3}{*}{ Uygun } & Zamanı doğru \\
& & En ideal zaman \\
\cline { 2 - 3 } Başlama Seviyesi & Öğrenciler iki yıl sınıflarından ayrılmamalı \\
& Uygun Değil & Değişimden kolay etkilenmeleri \\
& Daha erken dönemde alınması \\
& Okul öncesine alınması \\
& Kurs şeklinde planlanması \\
& Okuma yazma öğrendikten sora uygulanması \\
\hline
\end{tabular}

Uyum sınıflarının başlama zamanına dair görüşlerin yer aldığı Tablo 6 incelendiğinde, uyum sınıflarının 3.sınıflarda başlamasını uygun bulan ve uygun bulmayan iki kategorinin oluştuğu görülmektedir. Ancak zamanın uygun olduğunu savunan 2 katılımcı bulunmaktadır. Katılımcıların büyük çoğunluğu okul öncesi dönemde öğrencilerin uyum sınıflarına alınmasının gerekliliği üzerinde durmuşlardır.

Uyum sınıflarının zamanının uygun olmadığını savunan katılımcı Ö7; “Arkadaşlar arasında hep konuşuyorduk. Ana sinıfindan başlasak... Yani direkt bana gelse çocuk... Yani hani sifirdan bana gelip eğitim-öğretim hayatına başlasa daha mantıkl olur... Ama şimdi arada kayıplar var ister istemez"; katılımcı Ö11 ise, "bir sinıfa giden öğrencinin uyum simıfina gitmesine gerek yok bence. Aslinda dil öğretimi anaokulunda da başlatılabilir.” katılımcı Ö14; "okula ilk başladığı zaman çocuk eğer okuma yazma öğrenmemişse birinci dönem sonunda kesinlikle bir uyum sinıfina alınmal. O bir dönemlik süre onun için yeterli bence"; katılımcı Y10 ise, "eğer uygulanacak ise en başından uygulanmall. Tekrardan simftan alp 'Sen gel buraya' demek yanlss. İlla uygulanacaksa birinci sinıftan uygulanmah."; katılımcı Y2; "Birinci sinıfta (veya) ana simıfindan başlayarak Türkçeyi öğrenmeye başlyyorlar Birinci sinıfta okuma yazma öğrendikten sonra ikinci sinıfta çocukları uyum simıfina almalıyız. Ama kısmi zamanlı almahıız, tam zamanı değil.” şeklinde savunmaktadır.

Uyum sınıflarının üçüncü sınıflarda başlamasının uygun olduğunu düşünen katılımcı Y3; "bence 3. Sinıf ideal, hatta desteklenebilir. 3. Sinfftan itibaren sadece uyum sinfi ile sintrh kalmayı ekstra zamanda yine Türkçe öğretimi yapılabilir. 1 ve 2 (sinıf) de zaten çocuklar okuma yazma üzerine gidiyorlar, okuma yazma derslerine. Hani 1 ve 2 (sınff) çocuğu sımıftan kopartp da Türkçe bilen çocuklarn arasında kopartp sadece Arapça bilen çocukların arasına koymak o çocuklar için inanılmaz bir derece kötülük olur." ifadeleriyle dile getirmiştir.

\section{Uyum sınıflarına öğrenci seçiminde ve değerlendirmesinde uygulanan türkçe yeterlik sınavı (TYS) ile ilgili Türkçe öğreticileri ve okul yöneticilerinin görüşleri}

Bu başlık altında uyum sınıfına öğrenci seçiminde ve eğitim sonrasında yapılan değerlendirme sınavına ilişkin Türkçe öğreticileri ve okul yöneticilerinin görüşleri doğrultusunda tema, kod ve kategorilere yer verilmiştir.

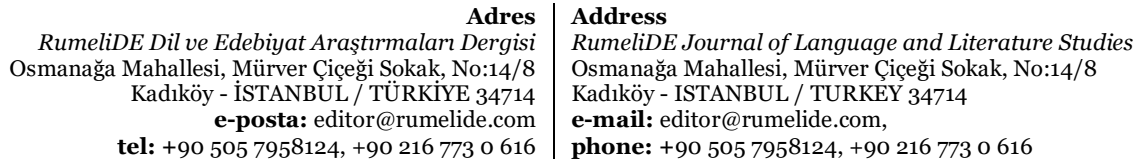


182 / RumeliDE Journal of Language and Literature Studies 2021.25 (December)

Opinions of Turkish language teachers and school administrators on the application of the integration class for Syrian students / S. Kapat; S. Şahin (pp. 169-194)

Tablo 7. Türkçe öğreticileri ve okul yöneticilerinin uyum sınıflarında uygulanan Türkçe yeterlik sınavı'na ilişkin görüşleri

\begin{tabular}{lll}
\hline Tema & Kategori & Kod \\
\hline & & Sözel beceri ifadelerinin ölçülememesi \\
& Yeterli sayıda soru olmaması \\
& İçerik boyutu & Sınav şeklinin uygun olmaması \\
& Görsellerin uygun olmaması \\
& Seviyenin üzerinde soruların olması \\
Türkçe Yeterlik Sinavı & Soru sayısının yetersiz olması \\
\cline { 2 - 3 } & Farklı dil becerileri ölçmemesi \\
& Kapsam geçerliği uygun olmaması \\
\hline & Sözlü bir format (mülakat) ile desteklenmemesi \\
\cline { 2 - 3 } & Öğretmenlerin de sürece katılmaması \\
& Öğretmenlerin söz hakkı olmaması \\
\hline Öğrenci Boyutu & Okuduğunu anlama probleminin olması \\
& Okuma yazma bilmemeleri \\
& Kodlama hatası yapmaları \\
& Sinavın anlaşılamaması \\
\hline
\end{tabular}

Uyum sınıflarına öğrenci alımında ve devam eden öğrencilerin değerlendirilmesinde kullanılan Türkçe Yeterlik Sınavı'na ilişkin görüşlerin yer aldığı Tablo 7 incelendiğinde Türkçe Yeterlik Sınavı'nın içerik boyutu, uygulama boyutu ve öğrenci boyutu olmak üzere üç kategorinin oluştuğu görülmektedir. TYS ile ilgili katılımcıların görüşleri paralellik gösterirken baskın görüş, sınavın sözlü mülakat ile desteklenmesi ve sınavın öğrenciler için çok ağır olduğu şeklindedir.

Öğrenci boyutu ile ilgili olarak Y11, "çocuklar zaten okuma yazma bilmiyorlar. Okuma yazma bilmeyen çocuğun önüne okuma-yazma gerektiren bir soru sorarsan çocuklarm başarısı ağlamasım bekleyemeyiz. Daha çok sözel sorular sorulabilirdi"; katılımcı Y2 ise, "Suriyeli çocukların en büyük problemi okuduğunu anlama problemi. Okuduklarından çok duyduklarmı anlıyorlar. 'Şunu yap, şunu getir, ellerini yıkacaksın!' (gibi sözlü ifadelerde) sıkıntı yok.”; katılımcı Ö10, “yani öğrenciler okuma yazmayı bile yeni öğreniyorlar. Yapılabilir bir sınav ama biraz daha kolay düzeyde olmal. Sinıfımızda okuması zayıf olup da Türkçe konuşabilen öğrenciler var. Çocuğa o soruları ben sorsam cevap verebilir bana ashında ama okuyamadiğ için zaten rastgele işaretlemiş çocuk...” şeklinde görüş belirtmiştir.

İçerik boyutu ile ilgili olarak katılımcı Öı, "dil gelişimini sadece yazılı sınavla ölçmek doğru değil. Tamamen somut bir sonuç vereceğini düşünmüyorum. Fakat yine (de) bir sinav yapmak, belli konulara değinmek öğrencinin ulaştığı seviyeyi ölçmek anlamında önemli”; katılımcı Ö6 ise, "bize verilen programda çocuk okuma yazma dinleme anlamaya yönelik kazamımları uygulamamız lazımdı. (Ancak TYS) sadece test mantığı...” şeklinde görüş belirtmiştir.

Uygulama boyutu ile ilgili olarak Y11; "çocuklar zaten okuma yazma bilmiyorlar. Okuma yazma bilmeyen çocuğun önüne okuma-yazma gerektiren bir soru sorarsan çocuklarm başarı sağlamasın bekleyemeyiz. Daha çok sözel sorular sorulabilirdi. \%30-\%40 yazılı \%6o da sözel sorular sorulabilir

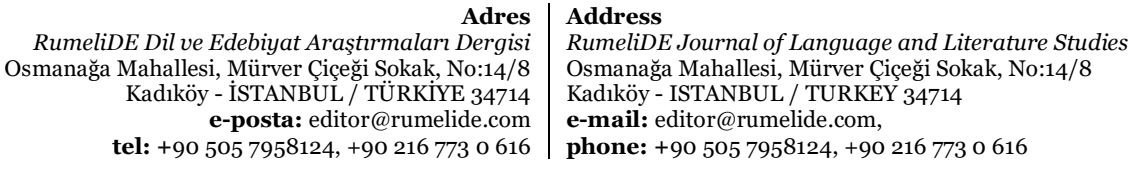


ve o şekilde normal sınıfa alınabilirdi. Okuma yazma bilmeyen, Türkçe bilen öğrenciler var sımıflarda. Maalesef sadece yazılı olarak değerlendirmek olumsuz diye düşünüyorum"; katılımcı Y12, "dil becerisini yazıl 3-5 soruyla ölçemeyiz. Türkçe öğreticilerinin de söz hakkı olmal. Türkçe öğreticisi görüş bildirdikten sonra komisyon tarafindan değerlendirilebilir"; katılımcı Ö11 ise, "ilkokulda kesinlikle öğretmenin (Türkçe öğreticisi) değerlendirmesinin olması lazım.” şeklinde görüş belirtmiştir.

\section{Uyum sınıflarının genel planlamasına ilişkin Türkçe öğreticileri ve okul yöneticilerinin görüşleri}

Tablo 8. Türkçe öğreticileri ve okul yöneticilerinin uyum sınıfı uygulamasının genel planlamasına ilişkin görüşleri

\begin{tabular}{|c|c|c|}
\hline Tema & Kategori & Kod \\
\hline & & Gelecek belirsizliği \\
\hline & Türkçe Öğreticileri & Öğretmenlerin teknik yetersizliği \\
\hline & & Plansızlığın olması \\
\hline & & Öğrencilere karne verilememesi \\
\hline & & Okuma kitabı eksikliği \\
\hline & Ĕ̆itim-öğretim & Okuma yazma kitaplarında a'dan başlanması \\
\hline & & Okuma yazma için 3-4 haftalık süre ayrılması \\
\hline & & Kitaplar ilkokul seviyesi için uygun olmaması \\
\hline & \multirow{11}{*}{ Sistem Açısından } & e-okul sisteminin oturmaması \\
\hline \multirow[t]{10}{*}{ Planlama } & & Öğretmenlerin not verememesi \\
\hline & & Öğretmenden beklentiler detaylandırılmaması \\
\hline & & Kervan yolda dizilir mantığının olması \\
\hline & & Günübirlik politikalar \\
\hline & & Ani değişikliklerin olması \\
\hline & & Planlama yetersizliği \\
\hline & & Materyal eksikliği \\
\hline & & Alt yapı eksikliği \\
\hline & & Tüm paydaşların görüşünün alınmaması \\
\hline & & Denetim eksikliği \\
\hline
\end{tabular}

Uyum sınıfı uygulamasının genel planlaması noktasında Türkçe öğreticileri ve okul yöneticilerinin görüşlerine göre hazırlanan Tablo 8 incelendiğinde; Türkçe öğreticileri, eğitim-öğretim ve sistem olmak üzere 3 kategoriden oluştuğu görülmektedir. Planlama başlı̆̆ında Türkçe öğreticileri ve okul yöneticilerinin görüşlerinin paralellik gösterdiği, Türkçe öğreticilerin tamamında yakını geleceklerinin belirsiz olması noktasında serzenişte bulunduğu, okul yöneticilerinin ağırlıklı olarak planlama başlığında görüş bildirdikleri, tüm katılımcıların özellikle öğrencilere karne verilememesini eleştirdiği görülmüştür.

Türkçe öğreticileri katılımcı Ö5, "gelecek sene için uyum sımıfı olmayacak deniyor. Sürekli bir belirsizlik, bir sistemsizlik olduğu için önümüzü göremiyoruz”; katılımcı Y5, "hep sonumuz ne olacak

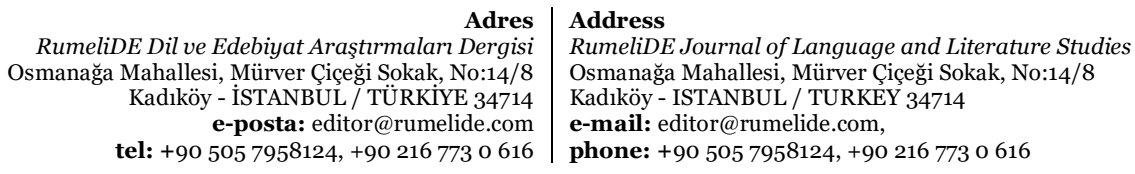


düşüncesindeler. İşimizden olur muyuz, ne kadar çalışacağız gibi sorunları hissediyorlar"; katılımcı Y2 ise, "(Türkçe öğreticileri) bizim akıbetimiz ne olacak, ben kendimi veremiyorum diyor. Yani deseler ki, kardeşim 10 yıl bende çalışacaksın ben de rahat edeceğim. Her yılsonunda geliyorsun sözleşme imzalara tazminatını alıp çııış yap, giriş yap adamın her türlü morali bozuk.” şeklinde ifade etmişlerdir.

Eğitim-öğretim kategorisinde öne çıkan nokta 2019-2020 eğitim-öğretim ylının birinci dönemin sonunda öğrencilere karne verilememesi hususuna katılımcı Ö7, "karne günü gerçekten çok kötü bir gündü. Yani çocuklar bunu mu vereceksiniz (diye sordular), bir de şöyle bir şey oldu bir kağıt parçası verdik resmen. Hani takdir-teşekkür gibi kalın karton da gelmedi. En azından o şekilde olabilir de hani ne olduğunu hissedebilirler de ama hiçbir şekilde karne gibi değildi yani. Direkt ayrtm olduğu (algısı) ortaya çıtı. Çocuk geliyor bana diyor ki, tenefüste öğretmenim onun karnesi böyle değil, neden bizimki böyle değil. Biz Suriyeliyiz bize bu yüzden mi böyle verildi gibi sözlerle de karşılaştık yani ister istemez." ifadeleriyle değinmiştir.

Sistem kategorisinde katılımcı Y8, “çoğu zaman ben girdim devamsızlıların. Çünkü zaten onlar geç tanımlandılar. Tabii ki o da çocukların takibini zorlaşttrdı. Zaman zaman benim gözümden kaçanlar oldu. Telafi etmeye çalıştık. (E-okula) tanımlama noktasında da çok geç tanımlandılar. Şimdi yine sistemde tanıml değiller"; katılımcı Ö1, "e-okula kaydımı yapıldı ama not veya devamszzhk giremiyoruz."; katılımcı Ö4, "okuma destekli materyallerimiz olan Salih hikâye okuma seti geldi. Ondan sonra da okuma seti çıkmadı. Okuma kitaplarmız eksikti. Görseller özellikle çocuğun yaş seviyesi(-ne göre düzenlenebilirdi). Yaş seviyesi küçük olduğu için punto olarak da bir tık büyük 12 değil de 1416 olursa renkli puntolarla görselleri de olursa... Dinleme metinleri eksikliği bulunmakta.”; katılımcı Ö8, "belki bir altyapı olsaydı daha faydası olacaktı bir alt yapısı olmadiğı için direkt uyum sınıflarına geçiş yaptıklarından dolayı şu an için az çok sıkıntı yaşıyoruz.” şeklinde durumu özetlemiştir.

\section{Uyum sınıflarına tavsiyelere ilişkin türkçe öğreticileri ve okul yöneticilerinin görüşleri}

Tablo 9. Türkçe öğreticileri ve okul yöneticilerinin uyum sınıflarına yönelik tavsiyelere ilişkin görüşleri

\begin{tabular}{|c|c|c|c|}
\hline Tema & Kategori & \multicolumn{2}{|l|}{ Kod } \\
\hline & & \multicolumn{2}{|c|}{ Görsel-işitsel materyal eksikliğinin giderilmesi } \\
\hline & & \multicolumn{2}{|c|}{ Öğrencilerin seviyelerine göre filmlerin organize edilmesi } \\
\hline & & \multicolumn{2}{|c|}{ Akran eğitiminin kullanılması } \\
\hline & & \multicolumn{2}{|c|}{ Ek Türkçe dersi verilmesi } \\
\hline & Ĕgitim-öğretim & \multicolumn{2}{|c|}{ Ders materyallerinin eksikliğinin giderilmesi } \\
\hline & & \multicolumn{2}{|c|}{ Seviye gruplarının oluşturulması } \\
\hline Tavsiyeler & & \multicolumn{2}{|c|}{ Türkçe-Arapça sözlük temin edilmesi } \\
\hline & & \multicolumn{2}{|c|}{ Görsellerin çocukların seviyesine göre düzenlenmesi } \\
\hline & & \multicolumn{2}{|c|}{ Öğrenci seviyelerine seviyelerine göre kitap hazırlanması } \\
\hline & & \multicolumn{2}{|c|}{ Saha ziyaretleri yaygınlaştırılması } \\
\hline & & \multicolumn{2}{|c|}{ Ciddi planlama yapılması } \\
\hline & Nistemi & \multicolumn{2}{|c|}{ Öğrencilerin ders dışı zamanlarda desteklenmesi } \\
\hline & & \multicolumn{2}{|c|}{ Öğretmenlerin de görüşü alınması } \\
\hline & $\begin{array}{r}\text { RumeliDE Dil } \\
\text { Osmanağa Mahal } \\
\text { Kadıl } \\
\text { tel: }+\end{array}$ & $\begin{array}{l}\text { Adres } \\
\text { Dergisi } \\
\text { Jo:14/8 } \\
34714 \\
\text { de.com } \\
3 \text { o } 616\end{array}$ & $\begin{array}{l}\text { Address } \\
\text { RumeliDE Journal of Language and Literature Studies } \\
\text { Osmanağa Mahallesi, Mürver Ciceği Sokak, No:14/8 } \\
\text { Kadıköy - ISTANBUL / TURKEY } 34714 \\
\text { e-mail: editor@rumelide.com, } \\
\text { phone: +90 505 7958124, +90 } 216773 \text { o } 616\end{array}$ \\
\hline
\end{tabular}


Öğrencilerin sene kaybının önüne geçilmesi

Her sene değişiklik yapılmaması

Türkçe öğreticileri ve okul yöneticilerinin görüşlerine göre uyum sınıfı uygulamasına tavsiyeler noktasında hazırlanan Tablo 9 incelendiğinde; eğitim-öğretim ve sistem olmak üzere 2 kategoriden oluştuğu görülmektedir. Öneri noktasında katılımcıların büyük çoğunluğu materyal desteğinin genişletilmesi, akran öğretimi yönteminin kullanılması gerektiği belirtmiş; okul yöneticileri farklı olarak saha ziyaretlerinin yaygınlaştırılması gerektiğini belirtmişlerdir.

Eğitim-öğretim kategorisinde katılımcı Ö2; "(Uyum sinıflarının) şartları iyileştirilebilir. Materyal desteği verilmeli”; katılımcı Ö6; “çocuklarm seviyesine göre kitaplarm hazırlanması gerekir”; katılımcı Y2, "...burada akran eğitimi dediğimiz şey çok önemli. Bana göre öğretmen öğretmediği bir şeyi öğrencileri kullanarak öğretebilir.”; katılımcı Y10, “...çocuklara ek olarak kurs verilebilir. Hafta sonu veya okulun olmadığı diğer saatlerde özel kurslar verilebilir.” şeklinde görüş belirtmiştir.

Sistem kategorisinde katılımcı Y13, “...saha ziyaretleri yayginlaştırllmal, koordinatörlerle görüşme yapmamı gerekir.”; katılımcı Y2, "tek tavsiyem ciddi ve zamanında planlama yapılması...”; Ö6 katılımcısı, "planlamanın düzeltilmesi ve gözden geçirilmesi gerekir; katılımcı Ö14, uyum sinıflarmmn seviye grupları şeklinde düzenlenmesi hem ögrrencinin hem bizim işimizi kolaylaştıracaktır.” şeklinde görüş belirtmiştir.

\section{Tartışma ve sonuç}

İlkokullarda uyum sınıfı uygulamasını değerlendiren Türkçe öğreticileri ve okul yöneticilerinin görüşlerini incelemeyi amaçlayan bu araştırmada aşağıdaki sonuçlara ulaşılmıştır. Okul yöneticilerinin ve Türkçe öğreticilerinin görüşlerinin genel anlamda paralel olduğu gözlemlenmiştir. Katılımcıların görüşlerinin odak noktasını planlama eksiklikleri oluşturmuştur. Bu çalışmada; uyum sınıfların müstakil sınıf olarak uygulanması öğrenciler ve Türkçe öğreticileri açısından baskın avantajlı görüş olarak karşımıza çıarken, öğrencilerin akademik, duygusal ve sosyal gelişimlerini az da olsa olumlu etkilediği bulgularına karşın dil gelişimlerini genel olarak olumsuz etkilediği bulgusuna ulaşılmıştır. Türkçe öğreticilerinin planlama dışında genel olarak uygulamadan memnun oldukları bulgusuna ulaşılmıştır. Uyum sınıflarının başlama yaşı ve TYS ile ilgili genel bir eleştiri olduğu, planlama ile ilgili ciddi sorunlar olduğu sonucuna ulaşılmıştır.

Uyum sınıfı uygulamasını öğrenciler açısından değerlendiren katılımcılardan elde edilen veriler sonucunda öğrencilerin akademik anlamda geliştiği, uyum sınıfına alınan öğrencilerin kendi anadilini konuşan ve sınıflarında aynı seviyede öğrencilerin bulunması nedeniyle kendilerini daha rahat hissettikleri, daha kolay sosyalleştikleri ve özgüvenlerinde artış olduğu bulgularına ulaşılmıştır.

Uyum sınıflarını öğrenciler açısından değerlendiren katılımcılar, çeşitli dezavantajlarının olduğunu belirtmişlerdir. Buna göre, uyum sınıfı uygulaması sonucunda öğrencilerde izole edilme ve dışlanmışlık hissi yarattığı, dil gelişiminde çok önemli olan akran öğretiminin ve Türkçeye maruz kalmanın asgari seviyeye indiği görülmektedir. Sınırlı bir süre de olsa sınıflarından alınan öğrenciler daha rahat iletişim kuracakları akranlarının olmasından dolayı dil gelişimlerinde zayıflama olduğu ve uyum sağlamak isterken öğrencilerde uyum problemi yaşanmasına neden olduğu söylenebilir.

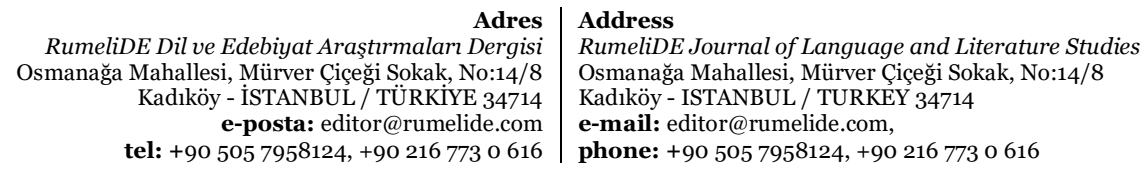


Opinions of Turkish language teachers and school administrators on the application of the integration class for Syrian students / S. Kapat; S. Şahin (pp. 169-194)

Okulda geçirdiği iki eğitim-öğretim yılında temel dil becerilerini edinemeyen öğrencinin kısa bir süre içerisinde Türkçeyi öğrenmesini beklemek düşünülmesi gereken bir konudur. Bir öğrencinin temel dil becerilerinden beklenen başarıyı göstermemesi öğrencinin diğer davranışlarını da etkileyecektir (Demirci, 2015). Milli Ĕ̆itim Bakanlığı'nın planları arasında yer alan akran kaynaşmasının sağlanması (MEB, 2016) temel dil becerilerinin eksikliğinden dolayı etkilenen davranışların ilk sıralarında gelmektedir. Suriyelilerle ilgili yapısal sorunlardan olan dil ve uyum sorununun üstesinden gelinmesi, çocukların topluma uyumunu hızlandıracaktır (Gencer, 2017). Suriyeli öğrencilerde izole hissi olması öğrencilerin motivasyonlarında düşüşe neden olduğu söylenebilir. Öğrencilerin motivasyonlarının düşmesi dil öğrenimlerini güçleştiren etkenler arasında sayılabilir (Biçer, 2016).Yabancı uyruklu öğrencilerin Türkçeyi anlamaları için Türk akranlarıyla iletişimde olması gerekmektedir (Börü, 2020; Takır ve Özerem, 2019). Kara vd. (2020) tarafından yapılan deneysel araştırmada, akranlarıyla iletişimde bulunan Suriyeli öğrencilerin Türkçeyi daha hızlı öğrendikleri sonucuna ulaşılmıştır.

Alanyazında dil konusunda benzer sonuçlara ulaşmak mümkündür. Takır ve Özerem (2019)'in çalışmasında, yabancı uyruklu öğrencilerde karşılaşılan en önemli sorunlar arasında dil sorunu olduğu sonucuna ulaşılmıştır. İmamoğlu ve Çalışkan (2017)'ın çalışmasında öğretmenlerin \%95’inin Suriyeli öğrencilerle iletişim kurulamamasından kaynaklanan sorunların meydana geldiği sonucuna ulaşmışlardır. Mercan Uzun ve Bütün (2016), araştırmaya katılan tüm katılımcıların üzerinde birleştikleri ortak noktanın öğrencilerin Türkçe bilmemelerinden kaynaklanan sorunların olduğu sonucuna ulaşmışlardır. Dil engeli, öğrencilerin izole edilmelerine ve yalnızlık hissi yaşamalarına neden olmakta ve daha ciddi sorunların meydana gelmesine neden olabilmektedir (Yohani, 2010 akt. Mercan Uzun ve Bütün, 2016). Erdem (2017) çalışmasında tüm katılımcıların ortak sorun olarak dil sorununu gördükleri sonucuna ulaşmıştır. Alanyazında yabancı uyruklu öğrencilerin en önemli sorununun dil problemi olduğu farklı çalışmalarda da belirtilmiştir (Özer vd., 2016; Sarıtaş vd., 2016; Levent ve Çayak, 2017; Öztürk vd., 2017; Bulut vd., 2018; Güngör ve Şenel, 2018; Kuzu Jafari vd., 2018; Moralı, 2018; İçöz, 2019; Sarıahmetoğlu, 2019; Şahin ve Sümer, 2018; Kandemir ve Aydın, 2020; Kara ve Özenç, 2020).

Uyum sınıfı uygulamasını Türkçe öğreticileri açısından değerlendiren katılımcılar Türkçe öğreticilerinin daha düzenli bir sistemlerinin (müstakil sınıf ve belirli öğrenciler) olduğunu belirtmişlerdir. Bu durum öğreticilerin okul içerisinde kendilerini daha rahat hissetmelerine, okula bağlllıklarının artmasına ve kendilerini öğretmen gibi hissetmelerine yol açmıştır.

Uyum sınıfı uygulamasının Türkçe öğreticileri açısından değerlendiren katılımcılarla yapılan görüşme sonucunda, uyum sınıflarının Türkçe öğreticileri açısından dezavantajlı yönlerinin de olduğunu sonucuna ulaşılmıştır. Buna göre, Türkçe öğreticilerinin uyum sınıflarında öğrenciler arasında seviye farkının fazla olmasını ve sınıf mevcutlarının yüksek olmasını dezavantaj olarak gördükleri tespit edilmiştir. Türkçe öğreticilerinin genel olarak uygulamadan memnun oldukları gözlemlenmiş ancak eksikliklerin giderilmesi, etkili bir planlamanın işletilmesi ve gelecek kaygılarının giderilmesiyle daha etkili öğretim süreci yürütebilecekleri sonucuna ulaşlabilir. Okul yöneticileri, Türkçe öğreticileri açısından genel durumu etkileyecek bir dezavantaj görmediklerinden dolayı pek görüş belirtmemişlerdir.

Uyum sınıfı uygulamasının başlama zamanı ile ilgili olarak katılımcıların büyük bir kısmı dil eğitiminin okul öncesinde başlamasının öğrenciler ve öğretmenler açısından daha faydalı olacağını belirtmişlerdir. Eğitim hayatına Türkiye'de başlayan yabancı uyruklu öğrencilerin okula başlarken çok az bildikleri veya hiç Türkçe bilmedikleri gözlemlenmektedir. Sınıf mevcutlarının yarısına ulaşan Suriyeli öğrenci sayısı

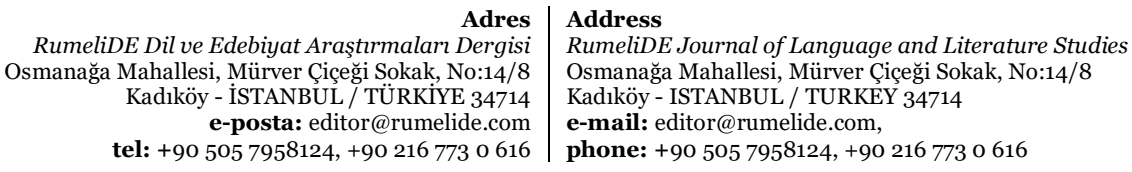


özellikle birinci sınıf öğretmenlerini çok yormaktadır. Bu süre zarfında okumaya geçen Suriyeli öğrenciler okuyabilmekte ancak okuduklarını anlamlandıramamaktadır. Bu durumun öğrencileri ve öğretmenleri yıprattığı sonucuna ulaşmak zor değildir. Öğrencilerin eğitim-öğretim sürecinden azami fayda sağlanması açısından öğrencilerin birinci sınıfa başlamadan önce temel dil becerileri eğitimi almaları önemli görülmektedir. Sarıtaş vd. (2016) çalışmasında, yabancı uyruklu öğrencilerin anasınıfları devam etmeleri ve sonucunda dil öğrenmesinin gerçekleşebileceği sonucuna ulaşmışlardır. Erdem (2017) çalışmasında mülteci öğrencilerin sınıflara dağıtılmadan önce dil eğitimine alınması gerektiğini belirtmiş̧tir. Dil eğitimin erken yaşlarda başlaması öğrencilerin dil, bilişsel ve duygusal gelişimlerini sağlamaları açısından önemlidir (Haznedar, 2003 akt. Turan ve Polat, 2017). Bulut vd. (2018), öğrencilerle iletişim kurulamamasının ve temel komutları bile anlamamanın temel nedeni olarak öğrencilerin dil becerisi kazanmadan okula gelmeleri olarak belirtmiştir. Kandemir ve Aydın (2020), öğrencilerin sınıflara dağıtılmadan önce dil eğitimi almaları gerektiği sonucuna ulaşmıştır.

Uyum sınıfına öğrenci alımı için yapılan yazılı bir sınav olan Türkçe Yeterlik Sınavı ile ilgili olarak katılımcıların çok büyük bir kısmı yazılı sınavın yanında mülakat veya sözlü sınav gibi bir uygulamanın mutlaka olması gerektiğini savunmuşlardır. Aynı zamanda TYS’nin öğrencilerin sadece okuma ve anlama becerilerini ölçtüğünü dinleme ve konuşma becerilerini ölçmekten uzak olduğunu belirtmişlerdir. Öğrencilerin dil becerilerinin ölçülmesi amacıyla yazılı olarak uygulanan TYS, öğrencilerin okuduğunu anlama becerilerinin ölçmektedir. Dil gelişiminde ölçülmesi gereken okuma, dinleme, konuşma ve yazma becerilerinin tamamını ölçmekten çok uzak olduğu anlaşılmaktadır. Bu kapsamda katılımcılardan elde edilen veriler doğrultusunda okullarda kurulacak olan mülakat komisyonu ile öğrencilerin değerlendirilmesi daha etkili sonuçlar ortaya çıkaracaktır. Mülakat sistemi ile katılımcıların da belirttiği gibi uyum sınıflarında Türkçe konuşabilen ancak okuma ve okuduğunu anlama becerileri zayıf öğrencilerin zaman kaybının da önüne geçilecektir. Altmışdört (2010), dil becerilerini ölçmek için uygulanan sınavlarda dil becerilerinin bütünleşik bir şekilde ele alınmasını ve bu kapsamda ölçme aracı geliştirilmesi gerektiğini belirtmiştir.

Görüşmelerde planlama noktasında tüm katılımcıların serzenişleri olduğu gözlemlenmiştir. Katılımcılarla yapılan görüşme 2019-2020 eğitim-öğretim yılının birinci döneminin sonuna denk gelmesinden dolayı öğrencilere karne verilmesi için planlama yapılmaması ciddi olarak eleştirilmiştir. Öğrencilerin ve öğretmenlerin bu durumdan olumsuz etkilendiklerini belirtmişlerdir. Türkçe öğreticilerinin e-okul sistemine bir türlü tanımlanamaması, Türkçe öğreticilerinin gelecekleri ile ilgili belirsiz durumların olması ve bu konuda resmi bir açıklama olmaması eleştirilerin odağını oluşturmaktadır. Planlama noktasında alanyazında çalışmalara ulaşmak mümkündür. Gencer (2017), öğrencilerin dışlanmamaları amacıyla sosyal adalet ve fırsat eşitliği sağlanmasını; Biçer ve Kılıç (2017) ders kitaplarının öğrenci seviyesine göre hazırlanmasını; Kuzu Jafari vd. (2018), materyal noktasında eksikliklerin olduğunu ve görsel materyal desteğinin sağlanmasını; Solak (2018), sınıf mevcutlarının azaltılması gerektiğini belirtmiştir.

Türkçe öğreticileri ve okul yöneticilerinin görüşleri doğrultusunda, uyum sınıflarının daha etkili ve verimli olabilmesi çeşitli öneriler sunulmuştur. Buna göre katılımcılar; görsel ve işitsel materyal desteğinin yapılması, öğrencilerin seviyelerine göre görsellerin hazırlanması, öğrencilerin seviyelerine göre kitapların hazırlanması, akran eğitiminin etkin bir şekilde kullanılması, ek Türkçe derslerin düzenlenmesi, planlamaların daha etkili bir şekilde yapılması, saha ziyaretlerinin yaygınlaştırılması, Türkçe öğreticilerinin de sürece dahil edilmesi önerilerini sunmuşlardır.

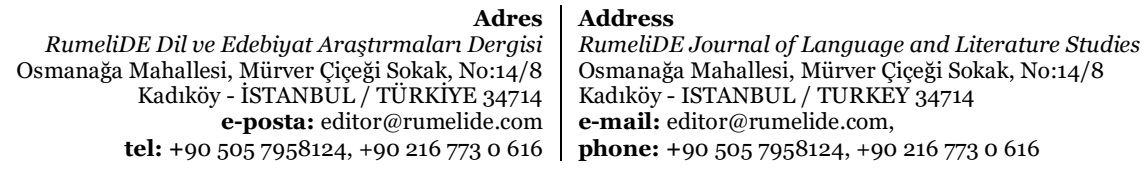


Araştırmadan elde edilen bulgulardan hareketle uyum sınıfı uygulamasının öğrenciler ve öğretmenler üzerinde olumlu sonuçları olmasına karşın bir takım dezavantajları da mevcuttur. En önemli sorun olarak öğrencilerin Türkçeye maruz kalmaması gösterilebilir. Öğrencilerin okula başlamadan önce dil eğitimi almaları üzerinde düşünülmesi gereken ciddi bir konu olarak görülmektedir. Türkçe öğreticilerinin gelecek kaygısı ve belirsizliği önemli sorunlar arasında yerini almaktadır. Türkçe Yeterlik Sınavı'nın sadece yazılı olması eleştirilen konular arasında yer almaktadır. Tüm katılımcıların bir noktada birleştiği konu, planlama eksiliği olmuştur.

\section{Öneriler}

1. Suriyeli öğrencileri okula uyumlarını hızlandırmak ve öğretim etkinliklerini daha verimli kılmak amacıyla okul öncesi dönemde dil eğitimleri düzenlenebilir.

2. Suriyeli öğrencilere velilere uyum sınıflarının ve dil eğitiminin amacı çeşitli etkinliklerle daha yoğun bir şekilde anlatılabilir.

3. Öğretmenler tarafından akran eğitimi yöntemi daha sıklıkla kullanılabilir.

4. Öğrencilerin daha verimli bir şekilde öğrenmesini sağlamak ve Türkçe öğreticilerinin iş yükünü hafifletmek amacıyla uyum sınıfları seviye grubu şeklinde düzenlenebilir.

5. Uyum sınıflarının mevcutları düşürülerek sürecin daha verimli bir şekilde yürütülmesi sağlanabilir.

6. Ölçme ve değerlendirme sisteminde Türkçe öğreticilerinin de söz hakkının olması ve mülakat yöntemiyle öğrencilerin farklı yönlerinin de ölçülmesi sağlanabilir.

7. Türkçe öğreticilerinin gelecek belirsizliği giderilerek öğreticilerin motivasyonlarının arttırılması sağlanabilir.

8. Öğrencilerin sınıflarından alınmadan Türkçe kurslarının düzenlenmesi gerçekleştirilebilir.

\section{Kaynakça}

Altmışdört, G. (2010). Yabancı dil öğretiminde nasıl bir ölçme-değerlendirmeye gerek vardır. Kuramsal Eğitimbilim Dergisi, 3(2), 175-200

İstanbul Bilgi Üniversitesi Çocuk Çalışmaları Birimi (2015). Suriyeli Mülteci Çocuklarnn Türkiye Devlet Okullarindaki Durumu: Politika ve Uygulama Önerileri. İstanbul.

Biçer, N. (2016). Yabancılara Türkçe Öğretiminde Motivasyona İlişkin Öğrenci Görüşleri ve Sınıf içi Gözlemler/Views of Students about their Motivation in Teaching Turkish as a Foreign Language and Classroom Observations. Ana Dili Eğitimi Dergisi, 4(1), 84-99.

Biçer, N., \& Kılıç, B. S. (2017). Suriyeli öğrencilere Türkçe öğretmek için kullanılan ders kitaplarının öğretmen görüssleri doğrultusunda değerlendirilmesi. Ana Dili Eğitimi Dergisi, 5(4), 649-663.

Börü, N. (2020). Yabancı uyruklu öğrencilere okuma yazma öğretimi. Journal of Social and Humanities Sciences Research, 7(55), 1840-1849.

Bulut, S., Kanat Soysal, Ö., \& Gülçiçek, D. (2018). Suriyeli öğrencilerin Türkçe öğretmeni olmak: Suriyeli öğrencilerin eğitiminde karşılaşılan sorunlar. Uluslararası Türkçe Edebiyat Kültür Eğitim Dergisi, 1210-1238.

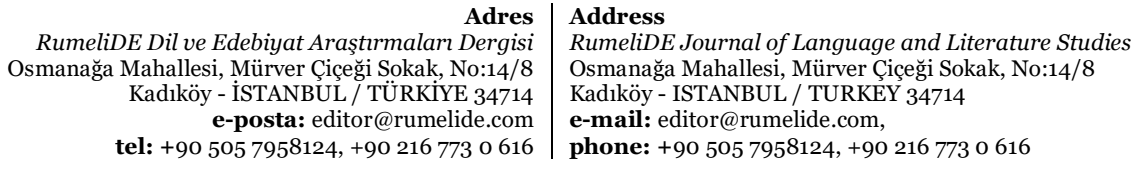


Büyüköztürk, Ş., Kılıç, E., Aygün, Ö. E., Karadeniz, Ş., \& Demirel, F. (2018). Eğitimde bilimsel araşttrma yöntemleri. Ankara: Pegem Akademi.

Burçak-Kılınç, B. (2019). İlkokula devam eden yabancı uyruklu öğrenciler ile T.C. Vatandaşı öğrencilerin birlikte eğitim almaları ile ilgili veli ve öğretmen görüşlerinin karşılaştırılması (Yayımlanmamış yüksek lisans tezi). İstanbul Aydın Üniversitesi, İstanbul.

Cırıt-Karaağaç, F., \& Güvenç, H. (2019). Resmi ilkokullara devam eden Suriyeli mülteci öğrencilerin eğitim sorunları. Uluslararası Toplum Araştırmaları Dergisi, 530 - 568 DOI: 10.26466/opus.530733.

Creswell, J. W. (2013). Nitel araştırma yöntemleri. Ankara: Siyasal.

Creswell, J. W. (2019). Nitel araştırmalar için 30 temel beceri. Ankara: Anı Yayıncılık.

Çimşir, S., \& Baysal, Z. (2020). Yabancı uyruklu ilkokul öğrencilerinin öğretmenleri ve ders başarıları ile ilgili yaşadıkları sorunların ve çözüm yollarının kendi bakış açılarından incelenmesi. Medeniyet Eğitim Araştırmaları Dergisi, 28-45.

Demirci, M. (2015). B1 seviyesinde Türkçe öğrenen Suriyeli öğrencilerin sesli okuma becerisiyle ilgili tespitler. Turkish Studies International Periodical for the Languages, Literature and History of Turkish or Turkic, 333-358. DOI:http://dx.doi.org/10.7827/TurkishStudies.8149

Erdem, C. (2017). Sınıfında mülteci öğrenci bulunan sınıf öğretmenlerinin yaşadıkları öğretimsel sorunlar ve çözüme dair önerileri. Medeniyet Eğitim Araşttrmaları Dergisi, 26-42.

Geçici Koruma Yönetmeliği (2014, 22 Ekim). Erişim adresi: https://www.resmigazete.gov.tr/eskiler/2014/10/20141022-15-1.pdf

Gencer, T. E. (2017). Göç ve eğitim ilişkisi üzerine bir değerlendirme: Suriyeli çocukların eğitim. Uluslararast Sosyal Araştırmalar Dergisi, 839-851.

Güngör, F., \& Şenel, E. (2018). Yabancı uyruklu ilkokul öğrencilerinin eğitim - öğretiminde yaşanan sorunlara ilişkin öğretmen ve öğrenci görüssleri. Anadolu Journal of Educational Sciences International, 124-173 DOI: 10.18039/ajesi.454575.

İçöz, H. (2019). İlkokullarda Yabancı uyruklu Öğrencilerle İlgili Karşılaşılan Sorunlar(Yayımlanmamış Yüksek Lisans Tezi).Akdeniz Üniversitesi, Antalya.

İmamoğlu, H. V., \& Çalışkan, E. (2017). Yabancı uyruklu öğrencilerin devlet okullarında ilkokul eğitimine dair öğretmen görüşleri: Sinop ili örneği. Karabük Üniversitesi Sosyal Bilimler Enstitüsü Dergisi, 529-546.

Kandemir, A., \& Aydın, B. (2020). Yabancı uyruklu öğrencilerin eğitimi ile ilgili yönetici ve öğretmen görüşleri. Uludağ Üniversitesi Ĕ̆itim Fakültesi Dergisi, 497-521 DOI: 10.19171/uefad.554653.

Kara, M., \& Özenç, M. (2020). A Multidimensional Approach to the Problems Experienced by the Classroom Teachers With Syrian Students in Their Classes. International Journal of Progressive Education, 16(6). DOI: 10.29329/ijpe.2020.280.11

Kara, M., Şahin, S. \& Kapat, S . (2020). Yabancı Uyruklu Öğrencilerin Türkçe Öğrenme Sürecinde Akran Öğretiminin Etkisi: Deneysel Bir Çalışma . OPUS Uluslararası Toplum Araştırmaları Dergisi , Eğitim ve Toplum Özel sayısı , 5974-5994 . DOI: 10.26466/opus.730411

Karataş, Z. (2015). Sosyal bilimlerde nitel araştırma yöntemleri. Manevi Temelli Sosyal Hizmet Araştırmaları Dergisi, 62-80.

Kuzu Jafari, K., Tonga, N., \& Kışla, H. (2018). Suriyeli öğrencilerin bulunduğu sınıflarda görev yapan sınıf öğretmenlerinin görüşleri ve uygulamaları. Academy Journal of Educational Sciences, 134146 DOI: $10.31805 /$ acjes.479232.

Levent, F., \& Çayak, S. (2017). Türkiye'deki Suriyeli öğrencilerin eğitimine yönelik okul yöneticilerinin görüşleri. Hasan Ali Yücel Eğitim Fakültesi Dergisi, 21-46.

MEB, (2016). "Suriyeli çocukların eğitimi için yol haritası belirlendi”. https://www.meb.gov.tr/suriyelicocuklarin-egitimi-icin-yol-haritasi-belirlendi/haber/1175o/tr , Erişim Tarihi: 08/12/2020).

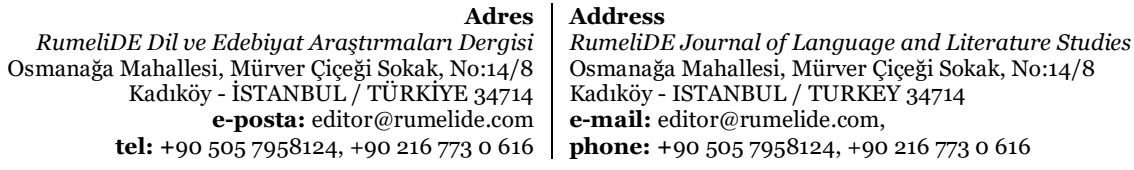


MEB (2019). 2019/15 nolu genelge. Erişim adresi: http://mevzuat.meb.gov.tr/dosyalar/2022.pdf Erişim tarihi: 06/12/2020

Mercan Uzun, E. \& Bütün, E., (2016). Okul öncesi eğitim kurumlarındaki Suriyeli sığınmacı çocukların karşılaştıkları sorunlar hakkında öğretmen görüşleri. Uluslararası Erken Çocukluk Eğitimi Çalışmaları Dergisi, 72-83.

Merriam, S. B. (2018). A Guide to Design and Implementation (3. Baskı). (S. Turan, Çev. Ed.). Ankara: Nobel (2009).

Moralı, G. (2018). Suriyeli mülteci çocuklara Türkçenin yabancı dil olarak öğretiminde karşılaşılan sorunlar. Uluslararası Toplum Araştırmaları Dergisi, 1426-1449 DOI: 10.26466/opus.443945.

Onat Kocabıyık, O. (2016). Olgubilim ve gömülü kuram: Bazı özellikler açısından karşılaştırma. Trakya Üniversitesi Eğitim Fakültesi Dergisi, 55-66.

Özer, Y. Y., Komşuoğlu, A. \& Ateşok, Z. Ö. (2016). Türkiye'deki Suriyeli çocukların eğitimi: Sorunlar ve çözüm önerileri. Akademik Sosyal Araştırmalar Dergisi. 4(37), 185-219.

Özenç, M., \& Kara, M. (2021). Problems faced in the education of Syrian immigrant students and solution recommendations: The Turkey case Psycho-Educational Research Reviews, 10(2), 142162. Retrieved from https://www.journals.lapub.co.uk/index.php/perr/article/view/1759

Öztürk, M., Tepebaş Cengiz, G. Ș., Köksal, H., \& İrez, S. (2017). Sinıfinda Yabancı Uyruklu Öğretmenler İçin El Kitabı. (Ed. S. AKTEKIN). Ankara: Millli Eğitim Bakanlığı.

Paker, T. (2015). Durum çalışması. (Çev.Ed.F. N. Seggie ve Y. Bayyurt), Nitel araştırma yöntem, teknik, analiz ve yaklaşımları. Ankara: Anı Yayıncılık.

Patton, M. Q. (2014). Nitel araştırma ve değerlendirme yöntemleri. (M. Bütün ve S. B. Demir, Çev. Ed.). Ankara: Pegem Akademi.

PİKTES, (2020a). Proje Hakkında. Erişim Adresi: https://piktes.gov.tr/ Erişim tarihi: 06/12/2020.

PİKTES, (2020b). Uyum Sinıfları İle İlgili Sıkça Sorulan Sorular. Erişim adresi: http://piktes.gov.tr/izleme/Uploads/rehberlik/sss.pdf Erişim tarihi: 06/12/2020.

Sarıtaş, E., Şahin, Ü., \& Çatalbaş, G. (2016). İlkokullarda yabancı uyruklu öğrencilerle karşılaşılan sorunlar. Pamukkale Üniversitesi Sosyal Bilimler Enstitüsü Dergisi, 208-229.

Solak, A. (2018). Zorunlu göçler ve doğurduğu sosyal travmalar,(Ed.) V. Özpolat. Ankara: Hegem Yayınları.

Şahin, S. \& Sümer, S. (2018). The problems experienced in the integration process of Syrian students in to the Turkish Education System. Universal Journal of Educational Research, 6(5), 909-918. DOI: 10.13189/ujer.2018.060512

Şimşir, Z., \& Dilmaç, B. (2018). Yabancı uyruklu öğrencilerin eğitim gördüğü okullarda karşılaştığı sorunlar ve çözüm önerileri. İlköğretim Online, 1719-1737 doi 10.17051/ilkonline.2018.466425.

Sarıhmetoğlu, H. (2019). Yabancı uyruklu öğrencilerin eğitim sistemine uyumunda karşılaşılan sorunlar ve çözüm önerileri (Yayımlanmamış yüksek lisans tezi). Kastamonu Üniversitesi, Kastamonu.

Takır, A. \& Özerem, A . (2019). Göçle gelen yabancı uyruklu öğrencilerin okul ortamında karşılaştıkları sorunlar . Folklor/Edebiyat, 25( 639-657) . DOI: 10.22559/folklor.972

Tanrıkulu, F. (2017). Türkiye'de yaşayan Suriyeli çocukların eğitim sorunu ve çözüm önerileri. Liberal Düşünce Dergisi, 127-144.

Tanrısevdi, F., Yengin Sarpkaya, P., \& Sarpkaya, R. (2019). Eğitim örgütlerindeki kadın yöneticilerin cam tavan deneyimleri. Egitimde Nitel Araştrmalar Dergisi - Journal of Qualitative Research in Education, 1590-1617. doi: 10.14689/issn.2148-2624.1.7c.4s.13m.

Turan, M. \& Polat, F (2017). Türkiye’de öğrenim gören yabancı uyruklu ilköğretim öğrencilerinin karşılaştıkları sorunlar ve çözüm önerileri. (2017). Qualitative Studies (NWSAQS), 31-60 DOI: 10.12739/NWSA.2017.12.4.EoO34.

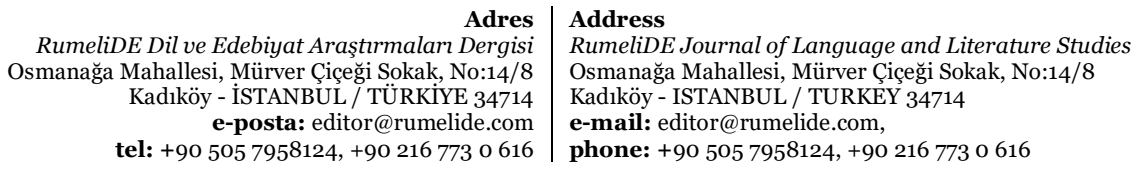


Tüzün, I. (2017). Türkiye'de mülteci çocukların eğitim hakkını ve karşlıklı uyumunu destekleyen yaklaşımlar, politikalar ve uygulamalar. Avrupa Liberal Forumu (ELF).

Uğurlu, Z. (2018). Suriyeli sığınmacı öğrencilerin okula uyum sorunlarının çözülmesi ve desteklenmesinde öğretmen etkisi. Şiddet ve Sosyal Travmalar, (s. 185-249). Samsun.

Yabancılar ve Uluslararası Koruma Kanunu. (2013, 11 Nisan). Resmi Gazete(Sayı: 28615 ) Erişim adresi: https://www.mevzuat.gov.tr/MevzuatMetin/1.5.6458.pdf

Yabancılara Yönelik Eğitim-Öğretim Hizmetleri Genelgesi (2014, 23 Eylül). Ankara: Milli Eğitim Bakanlığı. Erişim adresi: http://mevzuat.meb.gov.tr/dosyalar/1715.pdf

Yıldırım, A., \& Şimşek, H. (2018). Sosyal Bilimlerde Nitel Araştırma Yöntemleri. Ankara: Seçkin.

\section{Extended abstract}

\section{Introduction}

As a result of the internal turmoil in Syria, the Syrian people who wanted to escape from the civil war moved towards the Turkish border intensively and Turkey accepted the Syrians with its 'open door' policy. With the migration movement of Syrians, problems that must be overcome in society have emerged. The most important problem in education is the integration of Syrian students into the Turkish education system and the problem of not knowing Turkish. Various studies have been carried out in this regard (Foreigners and International Protection Law, 2013; Temporary Protection Regulation, 2014; Educational Services Circular for Foreigners, 2014). The inclusion of Syrian students in the education system in order to gain the right to education has brought along adaptation problems among students. In this context, the most serious problem emerges as the language problem. As a matter of fact, when the studies on foreign students are analyzed, it is seen that similar results have been reached in this regard (Istanbul Bilgi University, 2015:7; Sarıtaş et al., 2016; Mercan Uzun and Tüm, 2016:79; Erdem, 2017:39; Levent and Çayak, 2017:38). ; Tanrlkulu, 2017:132; Turan and Polat, 2017:58; Moral, 2018:1439-1422; Crrıt-Karaağaç and Güvenç, 2019:555; İçöz, 2019:44; Sarıhmetoğlu, 2019:111; Takır and Özerem, 2019 :14; Kandemir and Aydın, 2020:516; Özenç and Kara, 2021:151). In addition to these, it has been concluded that as students experience academic failure due to language problems (İmamoğlu and Çalışkan, 2017:543; Bulut et al., 2018:1236; Burçak-Kılınç, 2019:98; Çimşir and Baysal, 2020:41), they do not receive adequate support from their families in language education and cannot communicate adequately with their peers and teachers, they cannot socialize(Mercan Uzun and Tüm, 2016:75) and they have communication problems with their peers (Güngör and Şenel, 2018:165; Kuzu Jafari et al., 2018:143; Uğurlu, 2018:236; Şimşir and Dilmaç, 2018:1732). The most comprehensive of the practices carried out to solve this problem is the Project of Supporting the Integration of Syrian Children into the Turkish Education System (PICTES) conducted by the Ministry of National Education. PICTES, which is financially supported by the European Union, carries out studies to contribute to the access of children under temporary protection to the Turkish education system. This research which was carried out with the general aim of making the studies conducted within the scope of PICTES more efficient is considered important in terms of offering solutions to these problems by examining the positive and negative aspects of the adaptation class application from different perspectives. In addition, in line with the experiences of Turkish teachers and school administrators, it is considered important in terms of revealing the positive and negative aspects of adaptation classes and providing solutions, accelerating the adaptation to school and society as a result of the development of Syrian students' language skills, reducing the workload of teachers and managing a more efficient education process in the classroom environment, contributing to the development of social relations among students and peer teaching.

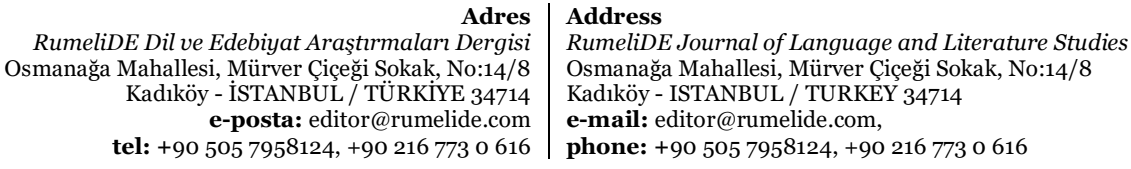


In this context, the main purpose of this research is to reveal the positive and negative aspects of the integration class application, which has been implemented since 2019 and to obtain data that will contribute to future applications.

Within the framework of this purpose, answers were sought to the following questions:

- What are the advantages and disadvantages of adaptation classes for students in line with the opinions of Turkish teachers and school administrators?,

- What are the advantages and disadvantages of adaptation classes for Turkish teachers?, what are their views on the starting level of adaptation classes?,

- What are their views on the content and application of the Turkish Proficiency Exam and what are their views on the planning of adaptation classes (organization, arrangement of the teaching process, provision of equipment and material support, arrangement of the process related to Turkish teachers)?,

- What are the recommendations for the adaptation classes to be more effective and efficient?

\section{Methodology}

In this study, the phenomenology method, one of the qualitative research designs, was used. For the study group, criterion sampling method, one of the purposive sampling methods, was preferred. The criteria used in determining the participants are for teachers to have taught foreign students for at least 2 years and for administrators to have worked in schools with adaptation classes. Interviews with the participants were carried out on a voluntary basis. The study group of the research consists of 27 people, 14 Turkish teachers and 13 school administrators. The data were collected through the interview technique using the semi-structured interview form. Research data were analyzed by content analysis method. Various measures were taken to ensure the validity and reliability of the research.

\section{Findings and discussion}

As a result of the data obtained from the participants who evaluated the adaptation class application in terms of students, it was found that the students improved academically, the students who were taken into the adaptation class felt more comfortable, socialized more easily and their self-confidence increased due to the presence of students speaking their mother tongue and having the same level in their classes.

Evaluating the adaptation classes in terms of students, the participants stated that they had various disadvantages. Accordingly, as a result of the adaptation class application, it is seen that students feel isolated and excluded, peer teaching and exposure to Turkish, which are very important in language development, are reduced to the minimum. It can be said that the students who are taken from their classes, albeit for a limited time, have peers with whom they can communicate more easily, so there is a weakening in their language development and while they want to adapt, they experience adaptation problems. A student's failure to show the expected success in basic language skills will also affect the student's other behaviors (Demirci, 2015:353). Ensuring peer cohesion, which is among the plans of the Ministry of National Education (MEB, 2016), comes first among the behaviors affected by the lack of basic language skills. Overcoming the language and integration problem, which is one of the structural

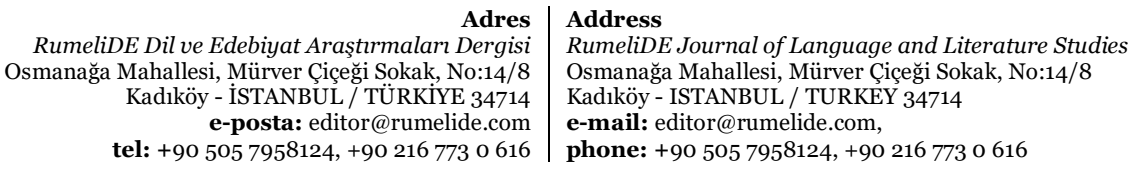


problems concerning Syrians, will accelerate the integration of children into society (Gencer, 2017:849). It can be said that the feeling of isolation among Syrian students causes a decrease in their motivation. The decrease in students' motivation can be counted among the factors that make language learning difficult (Biçer, 2016:97). Foreign students must be in connection with their Turkish peers in order to understand Turkish (Börü, 2020:1846; Takır and Özerem, 2019:671). In the experimental study carried out by Kara et al. (2020:5985), it was concluded that Syrian students who communicate with their peers learn Turkish faster.

The participants, who evaluated the adaptation class application in terms of Turkish teachers, stated that Turkish teachers had a more organized system (detached classroom and certain students). This caused the teachers to feel more comfortable in the school, to increase their commitment to the school and to feel like a teacher. As a result of the interviews with the participants who evaluated the adaptation class application in terms of Turkish teachers, it was concluded that the adaptation classes also had disadvantages for Turkish teachers. Accordingly, it was determined that Turkish teachers saw the difference in level among students in adaptation classes and the high class sizes as a disadvantage. It was observed that Turkish teachers are generally satisfied with the application, but it can be concluded that they can carry out a more effective teaching process by eliminating the deficiencies, applying an effective planning and eliminating their future concerns. As they did not see a disadvantage that would affect the general situation in terms of Turkish teachers, school administrators did not express much opinion.

Regarding the starting time of the adaptation class application, most of the participants stated that it would be more beneficial for teachers and students to start language education in pre-school. It is observed that foreign students who start their education life in Turkey know little or no Turkish when starting school. The number of Syrian students which reaches half of the class size is tiring especially for the first grade teachers. During this period, Syrian students who have started to read can read but cannot make sense of what they read. It is not difficult to conclude that this wears out students and teachers. It is considered important that students receive basic language skills training before starting the first grade in order to ensure maximum benefit from the education process of the students. In their study, Saritas et al. (2016:224) concluded that foreign students can learn language easily if they attend kindergartens. In his study, Erdem (2017: 39) stated that refugee students should be given language education, before they are distributed to classes. Starting language education at an early age is important for students' language, cognitive and emotional development (Haznedar, 2003 cited in Turan and Polat, 2017:50). Bulut et al. (2018:1223) stated that the main reason for not being able to communicate with students and students' not understanding even basic commands is that students come to school without acquiring language skills. Kandemir and Aydin (2020:511-512) concluded that students should receive language education before being distributed to classes. Regarding the Turkish Proficiency Exam which is a written exam for the admission of students to the adaptation class, most of the participants argued that an interview or an oral exam must be included in addition to the written exam. They also stated that TPE only measures students' reading and comprehension skills, and is far from measuring their listening and speaking skills. TPE, which is applied in writing to measure the language skills of the students, measures the reading comprehension skills of the students. It is understood that it is far from measuring all of the reading, listening, speaking and writing skills that must be measured in language development. In this context, in line with the data obtained from the participants, the evaluation of students by the interview commission to be established in schools will produce more effective results.

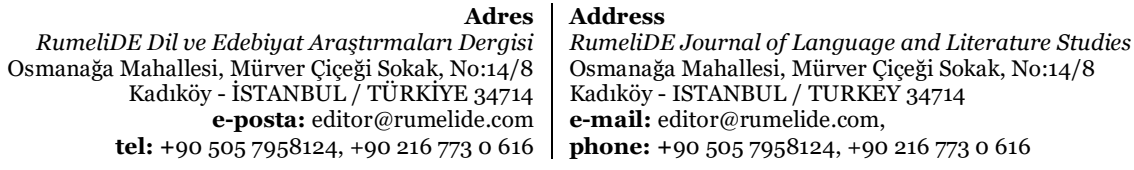


194 / RumeliDE Journal of Language and Literature Studies 2021.25 (December)

Opinions of Turkish language teachers and school administrators on the application of the integration class for Syrian students / S. Kapat; S. Şahin (pp. 169-194)

Based on the findings of the research, although the adaptation class application has positive results on students and teachers, there are also some disadvantages. The most important problem is that students are not exposed to Turkish. It is seen as a serious issue that students receive language education before they start school.

Adres | Address

RumeliDE Dil ve Edebiyat Araştırmaları Dergisi Osmanağa Mahallesi, Mürver Çiçeği Sokak, No:14/8 Kadıköy - İSTANBUL / TÜRKIYE 34714 e-posta: editor@rumelide.com

RumeliDE Journal of Language and Literature Studies Osmanağa Mahallesi, Mürver Çiçeği Sokak, No:14/8

Kadıköy - ISTANBUL / TURKEY 34714

e-mail: editor@rumelide.com

tel: +90 505 7958124, +90 2167730616 phone: +90 505 7958124, +90 2167730616 